\title{
Characteristics of subordinate follicles following removal of the dominant follicle: Induction of selection
}

\author{
Matthew Dean \\ West Virginia University
}

Follow this and additional works at: https://researchrepository.wvu.edu/etd

\section{Recommended Citation}

Dean, Matthew, "Characteristics of subordinate follicles following removal of the dominant follicle: Induction of selection" (2009). Graduate Theses, Dissertations, and Problem Reports. 2912.

https://researchrepository.wvu.edu/etd/2912

This Thesis is protected by copyright and/or related rights. It has been brought to you by the The Research Repository @ WVU with permission from the rights-holder(s). You are free to use this Thesis in any way that is permitted by the copyright and related rights legislation that applies to your use. For other uses you must obtain permission from the rights-holder(s) directly, unless additional rights are indicated by a Creative Commons license in the record and/ or on the work itself. This Thesis has been accepted for inclusion in WVU Graduate Theses, Dissertations, and Problem Reports collection by an authorized administrator of The Research Repository @ WVU. For more information, please contact researchrepository@mail.wvu.edu. 
Characteristics of Subordinate Follicles F ollowing Removal of the Dominant Follicle: Induction of Selection

$$
M \text { atthew Dean }
$$

Thesis

Submitted to the Davis College of Agriculture, Natural Resources, and Design at West Virginia University

in partial fulfillment of the requirements for the degree of

Master of Science

In

Reproductive Physiology

Robert A. Dailey, Ph.D., Chair

E. Keith Inskeep, Ph.D.

Jorge A. Flores, Ph.D.

Morgantown, WV

2009

Keywords: follicular wave, ovulation rate, selection, follicle 


\section{Abstract \\ Characteristics of Subordinate Follicles Following R emoval of the Dominant \\ Follicle: Induction of Selection \\ $M$ atthew Dean}

In mammals, ovarian follicles begin as primordial follicles. Over time these follicles are gradually activated and begin growth. As they proceed, granulosal and thecal cells are acquired. Eventually, the follicles become dependent on FSH for survival. Two or three times each cycle, a transient increase in FSH allows a cohort of follicles, including the follicle that will ovulate, to continue growing. However, these follicles secrete inhibin and estradiol, which suppress FSH secretion. Eventually, all the follicles of the cohort undergo atresia due to the declining concentrations of FSH, except for the follicle which has the potential to ovulate. This follicle survives the decline in FSH because the granulosal cells of that follicle develop LH receptors that allow stimulation to keep the follicle healthy. The concentrations of estrogen and free insulin-like growth factor I are different in the selected follicles compared to the follicles that underwent atresia in the cohort of follicles. However, because the ovulatory follicle cannot be identified until after it is selected, it is difficult to study the initial changes causing selection. One phenomenon from which insights to selection can be gained is compensatory hypertrophy, which is the ability of an animal to maintain the same ovulation rate after removal of one ovary. This compensation occurs at the next estrus, unless the unilateral-ovariectomy is carried out at the end of the cycle. Therefore, the present study determined the fate of the subordinate follicles following removal of the selected follicle at different stages of the estrous cycle of the cow. Results indicated that if the dominant follicle of a second wave and the CL were removed at day 13 post estrus, the largest subordinate follicle remaining became dominant. However, all treatments later in thecycle resulted in regression of the remaining follicles and emergence of a new wave of follicles before ovulation. 


\section{Acknowledgements}

I would like to thank my committee for their support and guidance. I am indebted to Dr. Dailey for our brainstorming sessions and development of my critical thinking skills. I would like to thank Dr. Inskeep for his critiques in writing this manuscript and reviewing the literature. No one knows the literature in this field like him. Dr. Flores was able to provide a unique perspective, looking at things very differently than the others, for that I am thankful. I would like to thank all my fellow graduate students, past and present. I hope I have shared with you a fraction of what I have learned from you. I owe much to the undergraduates who have helped me at the farm and in the lab, particularly Paige. Finally, I would like to thank my family, Mom, Dad, and James. Without your support, I could never have finished this degree. 


\section{Table of Contents}

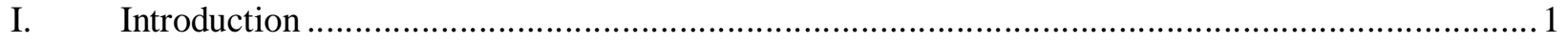

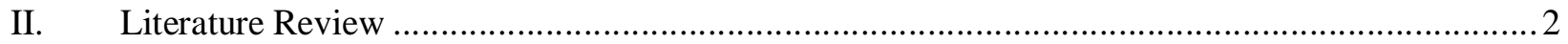

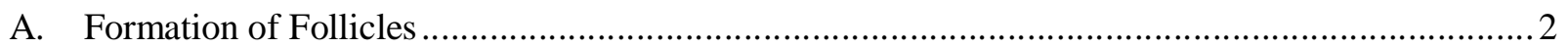

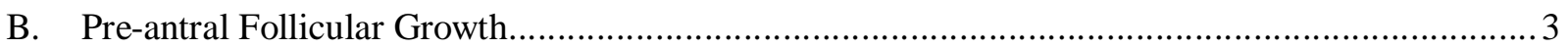

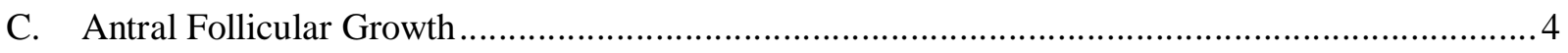

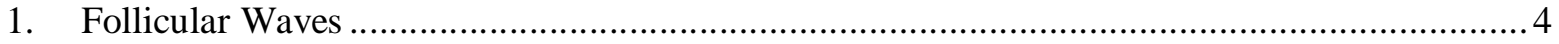

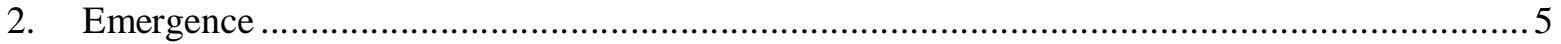

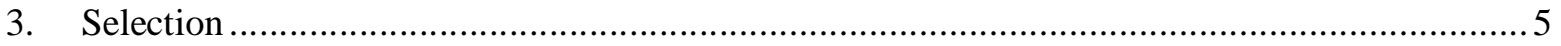

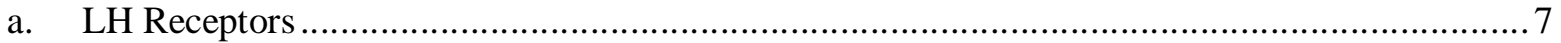

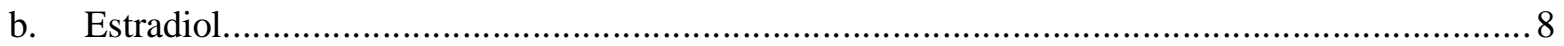

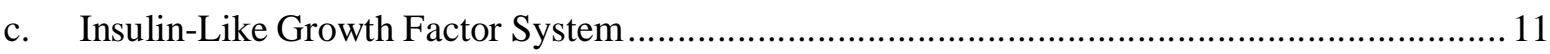

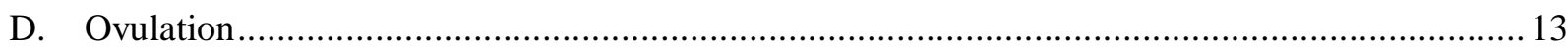

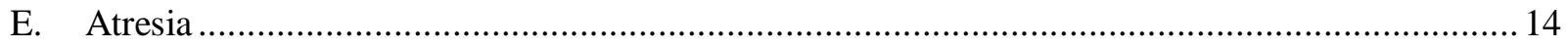

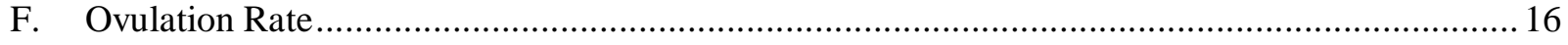

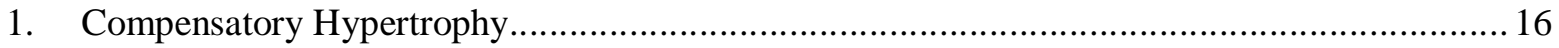

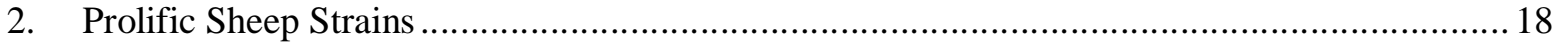

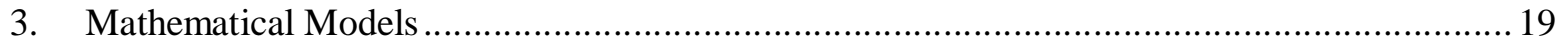

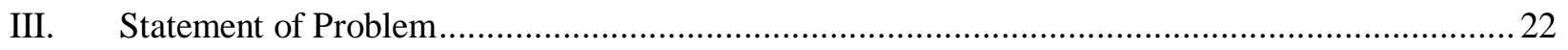

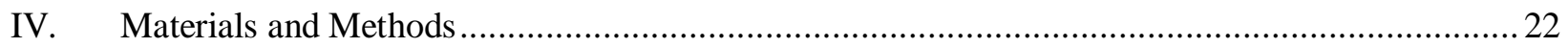

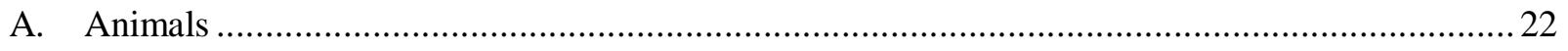

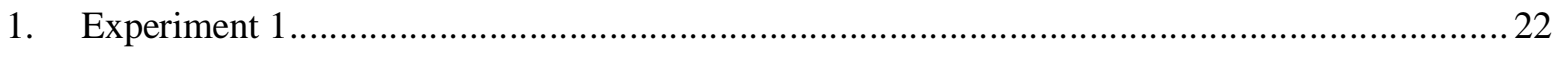

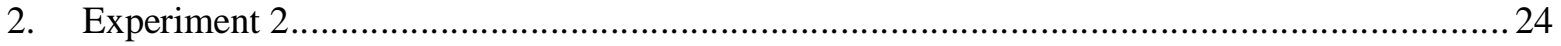

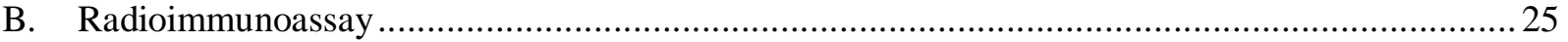

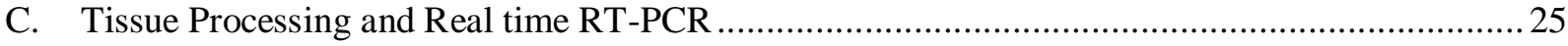

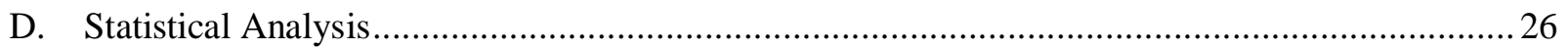

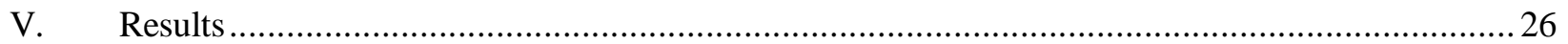

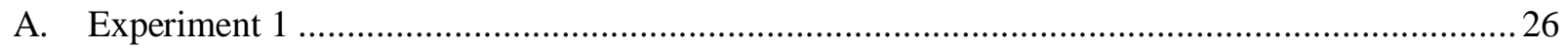

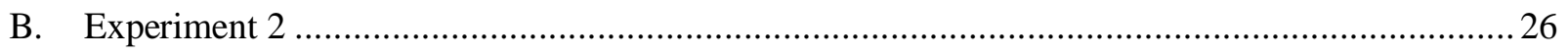

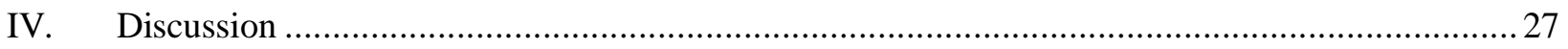

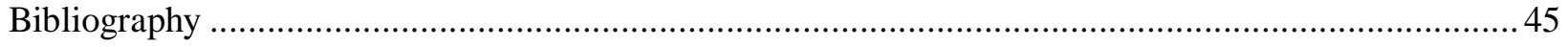




\section{List of Tables}

Table 1 Genes' name, primer sequence, product size and accession number of genes examined in thecal cells

Table 2 Characteristics of estrous cycles and follicles following ablation of the dominant follicle

*Ovulation was deduced as disappearance of a large follicle at next ultrasonography ...........................32

Table 3 Characteristics of estrous cycles and follicles following unilateral ovariectomy *Ovulation was deduced as disappearance of a large follicle by next ultrasonography ....

Table 4 Results of real-time RT PCR from mRNA harvested from thecal cells.................................. 34 


\section{List of Figures}

Figure 1 Example of two follicular waves in a control cow *W represents the follicular wave and $\mathrm{F}$ represents the ranking of the follicle within each wave.

Figure 2 Example of three follicular waves in a control cow $* \mathrm{~W}$ represents the follicular wave and $\mathrm{F}$

represents the ranking of the follicle within each wave.

Figure 3 Example of induction of a third follicular wave following ablation of the dominant follicle on day $17 \mathrm{*W}$ represents the follicular wave and $\mathrm{F}$ represents the ranking of the follicle within each wave,

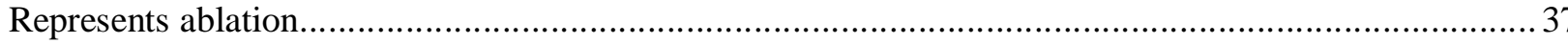

Figure 4 Example of Induction of a third follicular wave following ablation of the dominant follicle on day $19 * \mathrm{~W}$ represents the follicular wave and $\mathrm{F}$ represents the ranking of the follicle within each wave,

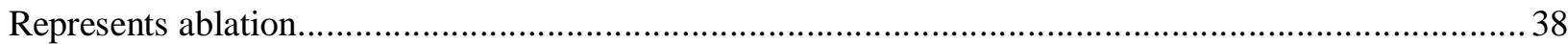

Figure 5 Growth of subordinate follicles following unilateral ovariectomy on day $13 * \mathrm{~W}$ represents wave,

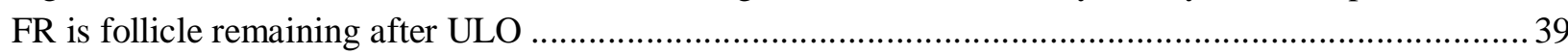

Figure 6 Growth of subordinate follicles following unilateral ovariectomy on day $15 * \mathrm{~W}$ represents wave,

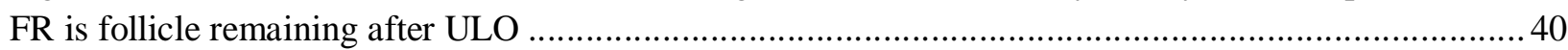

Figure 7 Concentrations of LH for the first 12 hours after surgery ........................................... 41

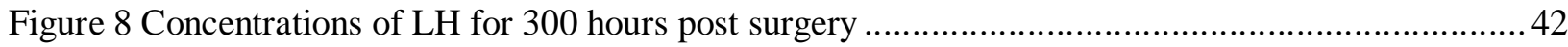

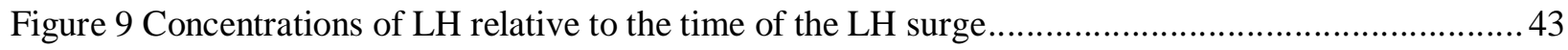

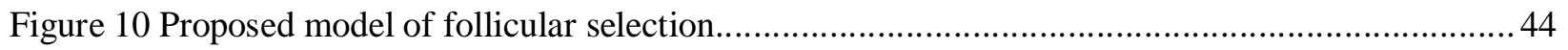


I. Introduction

Reproduction is essential for survival of a species. In each reproductive cycle of female mammals, the two ovaries release one to several ova, which, if fertilized, result in pregnancy. The two major reproductive structures of the ovary are the growing follicles and the corpus luteum (CL, plural corpora lutea). Each mature follicle contains an oocyte, granulosal cells, and thecal cells which produce estrogen. Granulosal cells surround the oocyte and line the edge of a fluid filled cavity, the antrum. The oocyte, granulosal cells, and antrum are enclosed by a basement membrane, and thecal cells line the outside of the basement membrane. After ovulation (rupture of a follicle and release of the oocyte), a CL is formed by luteinization of the remaining follicular cells. Luteinized granulosal and thecal cells, now termed large and small luteal cells, respectively, produce progesterone. Therefore, the CL is a heterogeneous structure composed of luteinized granulosal and thecal cells, as well as vascular, supporting, and immune cells.

The ovaries produce hormones that are essential for reproduction to occur. Follicles produce several hormones, the most important of which is estrogen. Estrogen has a wide array of actions, including regulation of hormonal release from the hypothalamus and pituitary, modulation of follicular growth, and initiation of estrus (mating behavior) in some species. If pregnancy is not achieved, the uterus of most species begins to produce prostaglandin $F_{2 \alpha}$, which causes regression of the CL (luteolysis). Luteolysis allows ovulation of a new oocyte and formation of a new CL. Thus, a new reproductive cycle begins. This literature review will focus on follicular growth, giving particular attention to factors important in selection of the ovulatory follicle. 


\section{A. Formation of Follicles}

Primordial germ cells (PGCs) are the direct precursors of oocytes. They are dipoloid cells (contain a full complement of DNA) that develop in the yolk sac of the embryo and migrate to what will become the gonad. During this migration the PGCs undergo several rounds of mitosis and then begin meiosis. Meiosis is the process by which haploid (contain only half the normal complement of DNA) cells are produced. During meiosis, the DNA replicates as the cell divides, producing two cells with a full complement of DNA. However, these two cells divide again without replication of DNA, resulting in four haploid daughter cells. The PGCs proceed into the first cell division of meiosis; however, the process becomes arrested after the first prophase.

Primordial follicles form when the PGCs colonize the developing gonad and recruit cells from the ovarian epithelium and stroma to form pre-granulosal cells (Fortune, 2003). This occurs in utero or shortly after birth and has been proposed to result in a non-renewable pool of follicles from which the female will draw for her entire life (Waldeyer, 1870). This idea had been generally accepted by reproductive biologists (reviewed in Tilly et al., 2009), but has recently been challenged by several lines of evidence.

The first modern report contradicting this belief compared the number of primordial follicles present in the ovary to the number of primordial follicles expected after the follicular reserve at birth as adjusted to account for atresia or ovulation (Johnson et al., 2004). The finding of more follicles than expected led the authors to conclude that the increased number of follicles must be the result of neoogensis. While this study was conducted in rodents, it corroborated an earlier study in non-human primates (Vermande-Van Eck, 1956). Another line 
of evidence supporting post-natal neoogensis resulted from treating mice with doxorubicin, which induces apoptotic cell death in oocytes. As expected, treatment resulted in an $80 \%$ decrease in the primordial follicle reserve. The surprising finding was a replenishment of the primordial reserve two months later (Johnson et al., 2005).

However, there are several lines of evidence supporting the idea that females are unable to produce new follicles later in life. One is a study employing a mathematical model to predict follicular dynamics concluded the rate of follicular depletion was adequately explained by accounting for follicular atresia and so supporting a lack of neoogensis (Bristol-Gould et al., 2006). The second line of evidence supporting this side of the issue was an inability to detect markers for germ cell proliferation in adult human ovaries (Liu et al., 2007). In short, the controversy surrounding formation of oocytes in adult ovaries is unsettled and ongoing.

\section{B. Preantral Follicular Growth}

Follicles are termed primary when they enter an irreversible growth phase characterized by granulosal cells becoming cuboidal and displaying markers for cellular proliferation (Wandji et al., 1996). Initiation of this growth has been linked to steroids (Yang and Fortune 2006, 2008) and vascular endothelial growth factor (Yang and Fortune, 2007), but their roles are poorly defined.

The next stage of development, secondary, is characterized by at least two layers of granulosal cells surrounding the oocyte; formation of a specialized layer of extracellular matrix around the oocyte, known as the zona pellicuda; and recruitment of thecal cells from ovarian connective tissue or stroma (Braw-Tal and Yossefi, 1997). In most species, secondary follicles continue uninterrupted into a tertiary or antral stage in which an antrum is present inside the follicle. In cattle, formation of an antrum occurs when a follicle is $0.5 \mathrm{~mm}$ in diameter 
(Fortune, 2003). Once begun, follicular growth continues uninterrupted until the antral stage, at which time follicles become dependent on gonadotropic support (Richards, 1980).

\section{Antral Follicular Growth}

\section{Follicular Waves}

Follicular growth was thought to be a continuous process in cattle until 1960, when Rajakoski (1960) proposed that follicular growth occurred in two waves during a normal bovine estrous cycle. This controversial idea, with reports supporting (Hackett and Hafs, 1969; Ireland, Coulson, and Murphree, 1979) or refuting (Choudary, Gier, and Marion, 1968; Donaldson and Hansel, 1972) it, was based on morphological observations of ovaries harvested during the estrous cycle.

Using India ink to identify follicles, Dufour et al. (1972) and Matton et al. (1981) studied follicular growth in cattle. Dufour et al. marked the storma surrounding the largest follicle per pair of ovaries and re-examined the ovary after the next estrus, while Matton et al. marked the two largest follicles on each ovary and then determined the fate of the marked follicles three to five days later. Matton et al. demonstrated that at least one of the largest follicles on the ovaries at day three was still present at day thirteen, confirming the first wave of Rajakoski's two-wave theory. However, none of the largest follicles marked by Dufour et al. on days 13 to 17 ovulated, refuting the purported second wave as the ovulatory wave.

In the 1980s, use of ultrasonographic technology allowed for multiple, non-invasive observations of ovarian follicles in individual animals. Pierson and Ginther $(1984 ; 1987)$ were the first to track follicular growth over time via ultrasonography and confirmed Rajakoski's hypothesis. However, other studies (Savio, Keenan, Boland, \& Roche, 1988; Sirois \& 
Fortune, 1988) concluded that follicular growth occurred in a three-wave pattern. In a study (Townson et al., 2002) of 106 Holstein dairy cows, 68\% of the cows exhibited two follicular waves during the estrous cycle studied, while $30 \%$ exhibited three follicular waves, and the remainder had one, four, or five waves. While the proportion of two- and three-wave cycles varied, together two- and three-wave cycles made up the vast majority (over 95\%) of estrous cycles in beef cattle and dairy heifers (Ginther, Knoph, and Kastelic, 1989; Ahmad et al., 1997).

\section{Emergence}

As shown after hypophysectomy in rodents, follicles can grow from primordial to antral stages without gonadotropic support (Edwards, et al., 1977). Hence, this growth has been termed gonadotropin-independent. Studies in the cow involving administration of a GnRH antagonist revealed that gonadotropin-independence ends when follicles have a diameter of 4

$\mathrm{mm}$ in this species (Gong et al., 1995). Hence, growth after this size is gonadotropin-dependent and represents the emergence of a follicular wave (Fortune, Sirois, and Quirk, 1988).

Follicle stimulating hormone is the gonadotropic hormone secreted by the pituitary gland that stimulates follicles during gonadotropin-dependent growth. Adams et al. (1992), used frequent blood sampling and ultrasonography to determine that the initiation of each follicular wave was associated with a transient increase (50-75\% above baseline) in the endogenous concentration of FSH. Each wave is composed of a group of follicles known as the cohort.

\section{Selection}

After a cohort of follicles is recruited for continued growth, serum concentrations of FSH begin to decline. By selectively ablating follicles of different sizes post-emergence, 
Gibbons et al. (1997) found that follicles $5 \mathrm{~mm}$ or larger contributed to the decline in concentrations of FSH. Follicles at that diameter in the cow are capable of secreting estrogen; however, estrogen did not fully account for the suppressive effects on FSH secretion. To investigate the possibility of an FSH suppressor besides estrogen, Law et al. (1992) treated animals with follicular fluid stripped of steroids with charcoal. Even without estrogen, follicular fluid that had been suppressed $\mathrm{FSH}$, suggestive of action by a protein in the follicular fluid. A major protein suspected of the action was inhibin.

Inhibin is a dimer with two isoforms (A and B). Both isoforms contain an $\alpha$ subunit, but inhibin $A$ has the $\beta A$ subunit, while inhibin $B$ contains the $\beta B$ subunit. However, the $\beta$ subunits can dimerize forming activin. Activin has three isoforms (A, B, A/B) depending on the subunits. Finally, follistatin, a single mono-unit protein, has similar biological actions as inhibin, however, these actions are due to follistatin binding activin and rendering it inactive. The inhibitory action of inhibin was confirmed when Wood et al. (1992) immunized against inhibin and prevented the suppressive effects of steroid-free follicular fluid. These effects can be counteracted by activin. However, these proteins also have intra-follicular effects. Inhibin increases androgen biosynthesis by the theca (Hsueh, et al., 1987). On the other hand, activin blocks this effect and increases mRNA expression for the FSHR in the granulosa (Findlay, 1993).

Exploring the relationship among these proteins in human beings, Schneyer et al. (2000) monitored components of the inhibin/activin/follistatin axis during the human menstrual cycle. While concentrations of inhibin B, activin A, and follistatin remained constant, inhibin A was associated with follicular maturity. Hence, they examined the ability of the follicle to produce inhibin A and B in vitro (Welt and Schneyer, 2001). Inhibin B was produced by the granulosal 
cells of preantral follicles and was not affected by FSH. Inhibin A was produced only by small antral follicles and its production was increased by FSH and insulin-like growth factor (IGF)-I. During the common growth phase, when all follicles of the cohort are growing synchronously, inhibin A from the entire cohort suppresses FSH. However, as the subordinate (non-selected) follicles undergo atresia, the sources of inhibin are lost, and the selected follicle becomes estrogen-active (Roche and Ireland, 1981). Estrogen replaces the negative feedback effects of inhibin on FSH secretion (Bodensteiner et al., 1996).

To explore the dependency of follicles on FSH, Ginther et al. (2000) treated cows with exogenous estradiol. Estrogen inhibits FSH secretion without affecting concentrations of LH. When concentrations of FSH were reduced before selection, growth of all follicles was decreased, showing their dependence on FSH. However, decreasing concentrations of FSH during selection affected the growth of only the follicle being selected, meaning that it was still dependent on FSH for survival.

In rodents, estrogen increases follicular sensitivity to FSH (Richards, 1980). Because the selected follicle is the only follicle to produce large amounts of estradiol (Xu et al., 1995), it utilized FSH for a longer interval during FSH's decline. However, eventually concentrations of FSH declined to a point where subordinate the selected follicle can no longer survive on only FSH.

\section{a. LH Receptors}

The granulosal cells develop LH receptors (LHR) at the same time that the selected follicle begins to secrete copious amounts of estradiol (Xu, et al., 1995). Campbell et al. (1999) suppressed concentrations of gonadotropins with a GnRH antagonist, then infused FSH and LH in different patterns to study follicular selection in sheep. When high concentrations of FSH 
were maintained, ovulation rates were greater than normal, regardless of LH concentration. However, when FSH infusion was withdrawn, mimicking natural FSH patterns, a normal number of follicles survived to ovulation when LH was present, but none survived when LH was absent. In fact, the selected follicle cannot grow past 7 to $9 \mathrm{~mm}$ in diameter if $\mathrm{LH}$ is suppressed (Gong et al., 1995) and, therefore, the selected follicle is LH dependent.

Receptors for LH develop on the granulosal cells of the selected follicle of the first wave in cows between days 2 and 4 post estrus (Bodensteiner et al., 1996; Xu et al., 1995). By evaluating gene expression of follicles across the first follicular wave, Bao et al. (1997) confirmed an increase in expression of LHR genes during selection. While FSHR mRNA was expressed in granulosa from the secondary stage of follicular growth and LHR mRNA was detected in the thecal cells of preantral follicles, LHR mRNA was not expressed in the granulosal cells until after selection. One defining characteristic of selection is the development of LH receptors on the granulosal cells. Presence of mRNA for the LH receptor may be an important aspect of a follicles ability to become dominant.

The activation of many signaling pathways has been detected prior to development of LH receptors. These pathways are believed to be involved with the development of LHR, but a definitive pathway has been difficult to establish. Elucidating the mechanism responsible for the development of $\mathrm{LH}$ receptors in the granulosa of only the selected follicle would benefit protocols in animal agriculture and human medicine aimed at altering ovulation rate.

\section{b. Estradiol}

Estrogens are a class of hormones that produce female characteristics in mammals (Concise Oxford American Dictionary, 2006). Estradiol-17 $\beta$, the major estrogen produced by the ovaries in mammals, is synthesized from cholesterol by enzymes located in granulosal and 
thecal cells. Production begins in the thecal cells where LH stimulates the production of androgens, hormornes that produce male characteristics (Concise Oxford American Dictionary, 2006) . This multi-step process begins with conversion of cholesterol to pregnenolone via P450 sidechain cleavage enzyme $\left(\mathrm{P} 450_{\text {scc }}\right)$. Next, pregnenolone is converted to progesterone by the $3 \beta$-hydroxysteroid dehydrogenase enzyme. Finally, androgen is produced by action of the 17 $\alpha$-hydroxylase and 17,20 lyase enzymes. Androgen then diffuses to the granulosal cells, where it is converted into estrogen by aromatase (Leung and Armstrong, 1980).

Estrogen has many important functions during follicular development, making steroidogenesis a control point for follicular growth. To investigate steroidogenic enzyme expression, Bao et al. (1997) analyzed follicles during growth of the first follicular wave. Gene expression for the FSH receptor (FSHR) was first detected within the granulosal cells of secondary follicles, and expression increased as follicular size increased. Expression continued to the largest follicles analyzed $(15.0 \pm 0.7 \mathrm{~mm}$ in diameter). The mRNA for the LHR was found in the thecal cells of all follicular sizes, but it was not detected in granulosal cells until follicles were $7.8 \mathrm{~mm}$ in diameter which is approximately the same diameter at which Ginther has determined that the growth rates of the selected and subordinate follicles become different (deviation; Ginther et al., 1997). Expression in the granulosa then increased significantly by $10.8 \mathrm{~mm}$ and remained constant until $15.0 \mathrm{~mm}$, when it again increased. In the thecal cells,

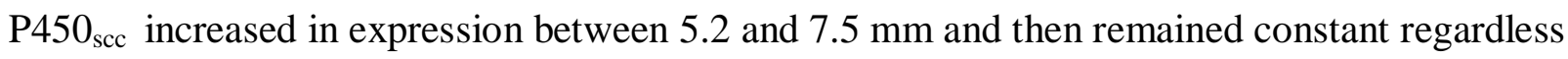
of size. However, expression in the granulosal cells increased slowly and steadily as size increased. Aromatase gene expression changed in the most telling fashion. Expression increased significantly between $5.2 \mathrm{~mm}$ and $7.5 \mathrm{~mm}$ (emergence) and then increased again between 7.8 and $10.8 \mathrm{~mm}$ (deviation). Changes in aromatase gene expression correlated well 
with stages of follicular growth. These results could be interpreted as estrogen playing a key role in follicular maturation.

To study the effects of estradiol on follicular growth, Beg et al. (2003) used progesterone to decrease LH pulse frequency which resulted in lower concentrations of estrogen or infused estrogen antiserum to lower estrogen availability directly. Both treatments had the extra-ovarian effects of increasing the concentration of FSH. Perhaps more interesting was the finding that both treatments increased the interval of time between emergence of the wave and follicular deviation. Yet, the size of the largest follicle at the time of deviation did not differ from controls, supporting an intra-follicular role for estrogen in controlling follicular maturation.

A well established control point for estrogen production is ovulation, as estrogen triggers the LH surge. To investigate control of estrogen production, Tian et al. (1995) induced luteolysis in cows while the selected follicle from the first wave was still dominant, and then they removed this follicle at either 0,12 , or 24 hours post injection. Estrogen production increased during luteolysis, and this increase was associated with mRNA expression for SCC, $3 \beta$-hydroxysteroid dehydrogenase, and 17 $\beta$-hydroxysteroid dehydrogenase, but aromatase mRNA did not increase. This could mean that the other enzymes are limiting estrogen production; although, mRNA expression may not reflect protein expression.

Dominant follicles initially have a high estrogen to androgen ratio due to high aromatase activity and are termed estrogen-active. As atresia begins, aromatase is lost resulting in high concentrations of progesterone; these follilces are termed estrogen-inactive (Ireland and Roche, 1982). It is likely that the fate of a follicle is determines by its ability to produce estradiol. In 
turn, estradiol production is control by many enzymes, two important of which is aromatase and $\mathrm{P} 450_{\text {scc. }}$

\section{c. Insulin-Like G rowth Factor System}

Much research has identified differences between selected and subordinate follicles. One difference consistently identified in selected follicles is an increase in free insulin-like growth factor (IGF)-I. The IGF system contains two ligands (IGF-I and - II), two receptors (IGFR-1 and IGFR-2), six high affinity IGF binding proteins (BPs), and several binding protein proteases. The IGF system regulates growth and development in most bodily organs and processes throughout the body (reviewed in Pinchas, 2008), including follicles (Boldt and Conover, 2007; Monniaux and Pisselet, 1994). However, results of studies looking at the IGF-I system are difficult to interpret. Early assays for IGF-I measured total IGF (bound to BPs and free). In the bound form, IGF has an altered affinity for its receptor. Most reports found that bound IGF has lowered affinity for its receptor (reviewed in Rosenfeld et al., 2000), but in some cases the affinity was increased (Elgin, Busby, and Clemmons, 1987). Also, concentrations of free IGF-I can be changed by changes in the translation, transduction, or post-translation modification of ligand, IGFBPs, or IGFBP proteases.

Original studies linking IGF-I to follicular dominance merely showed a correlation. However, Ginther et al. (2004) found that injecting free IGF-I into a subordinate bovine follicle increased its estrogen content and stimulated it toward dominance, showing a causative effect. Those results agree with those of Silva and Price (2002) who found that IGF-I increased aromatase expression in cultured granulosal cells. Ablation of the largest follicle (F1) increased free IGF-I in the second largest follicle (F2) 12 hours later in the cow (Beg et al., 2002) and before size deviation occurred in the horse (Ginther et al., 2002). The concept that IGF 
stimulation is critical for dominance is further supported by the finding of Grado-Ahuir et al. (2009) that IGF-I induced changes in gene expression in porcine granulosal cells that promoted vascularization. However, the origin of free IGF in the follicle remains ambiguous, because IGF-I mRNA was found in the granulosal cells by some researchers (Hastie and Haresign, 2008) but not by others (Sudo et al., 2007; Aad et al., 2006).

Whichever is the case, concentrations of total IGF do not seem to change during follicular growth. In human follicles, IGF concentrations were not correlated with follicular diameter (Van Dessel et al., 1996) and Sudo et al. (2007) found that IGFR-1 and total IGF-I were expressed similarly across all developmental stages of healthy follicles in cattle. However, free IGF did change (Sudo et al., 2007; San Roman and Magoffin, 1993).

Concentrations of free IGF could be controlled by changes in IGFBP concentrations. When co-dominant follicles were induced by injection of FSH, both follicles had the same concentrations of IGFBP- 4 as the dominant follicle of control animals, but lower IGFBP-4 concentrations than in the largest subordinate follicle in control animals (Rivera and Fortune, 2001). In turn, IGFBPs are controlled by changes in pregnancy associated plasma protein A (PAPP-A) expression, primarily a protease for IGFBP-4, but also for IGFBP-2 and 5. Growing follicles tended to have greater expression of PAPP-A mRNA; PAPP-A expression was increased in cultured granulosal cells by treatment with FSH alone but not estrogen (Sudo et al., 2007). However, Aad et al. (2006) found that estrogen increased PAPP-A mRNA expression in the theca of large follicles. Culturing equine chorionic gonadtropin (eCG)- primed rat granulosal cells with IGFBP-7 decreased aromatase expression and estrogen production in an IGF-independent manner (Tamura et al., 2007). Hence, IGFBPs may have roles other than binding IGF. 
Free IGF has been correlated with status of a follicle after deviation by numerous authors. But, the amount of free IGF is controlled by a number of factors. An increase in free IGF could be the result in an increase the production of IGF or PAPP-A or a down-regulation of IGFBPs, specifically IGFBP-2 and -4 have been shown to vary with follicular status. Therefore, the epression of genes for these proteins could be indicative of a follicles ability to assume dominance.

\section{Ovulation}

Ovulation is the process by which the follicle ruptures and the oocyte is released into the oviduct. Traditionally ovulation has been viewed in two ways: as an inflammatory reaction and due to smooth muscle contraction (Espey, 1980). Similar to an inflammatory response, the LH surge causes an increase in blood flow to the ovary within minutes (Lee and Novy, 1978). Also, leukocytes accumulate in the ovulatory follicles in the hours after mating and before ovulation in the rabbit, an induced ovulator (Espey, 1974). The newly arrived basophils release histamine, which increases vascular permeability and edema; macrophages and thrombocytes release prostaglandins and proteolytic enzymes, all resembling an inflammatory response (Espey, 1980). Control of prostaglandin secretion is unclear, but oxytocin (Bridges and Fortune, 2007) and progesterone (Bridges, Komar, and Fortune, 2006) have been implicated. Within the follicle, prostaglandins (Espey et al., 1981) and progerone (Rondell, 1974) cause thinning of the follicular wall prior to ovulation.

Ovulation also can be seen as a result of ovarian contractility (Espey, 1978). Although smooth muscle is found in the ovaries of rats (O'Shea, 1970), human beings (Okamura, Virutamasen, and Wright, 1972), and cows (Walles et al., 1975) a wide discrepancy exists in the presence, location, and amount of muscle tissue, in part because numerous authors simply used 
the presence of cytoplasmic filaments as evidence for smooth muscle. Many authors described expulsion of follicular contents as oozing from the follicle (Blandau, 1967; Motta and Van Blerkom, 1975), which would not indicate muscle contraction. However, Pendergrass and Reber (1980) described the ovulation in hamsters as an eruption and concluded this to be indicative of muscle contraction. Indeed, the morphology of smooth muscle in the basal hemisphere of a hamster follicle changed as the follicle ovulated (Martin and Talbot, 1981a), and ovulation and the associated changes in the smooth muscle morphology were blocked by inhibiting smooth muscle contraction (Martin and Talbot, 1981b). These differences could be due to differences between species or differences in methods and interpretation of different laboratories, so the role of smooth muscle in ovulation remains unclear.

\section{E. Atresia}

Atresia, the death of a follicle (Krysko et al., 2008), is the fate of most follicles (over 99\%; Baker, 1963). In fact, the stockpile of germ cells is reduced from approximately one million before birth to about 300,000 at puberty. Of those remaining, only $0.1 \%$ will ovulate (Matova and Cooley, 2001). Atresia commonly occurs during one of two phases of follicular growth. The first is during follicular formation. Most follicles that undergo atresia do so before the primary stage. Once on the course of growth, little atresia occurs between the primary and antral stages. However, once follicles become gonadotropin-dependent, during the antral stage, atresia again starts to increase in frequency (reviewed in Richards, 1980).

Atresia of antral follicles is typically linked to apoptosis of the granulosal cells. Apoptosis is programmed cell death and is characterized by internucleosomal DNA fragmentation, cell shrinkage, plasma membrane blebbing, and formation of apoptotic bodies. 
Apoptosis is usually viewed as resulting from lack of growth/survival factors necessary for a particular cell type or the presence of pro-apoptotic factors (Matsuda-Minehata et al., 2006).

The cell death ligand-receptor systems in mammals include Fas ligand (FasL) and Fas, tumor necrosis factor- $\alpha$ (TNF- $\alpha$ ) and TNF- $\alpha$ receptors, and TNF- $\alpha$-related apoptosis-inducing ligand (TRAIL) and TRAIL receptors (reviewed in Matsuda-Minehata et al., 2006). Apoptosis is induced when these receptors trimerize with ligand. Once trimerized, the intracellular death domain (DD) binds to the Fas-associated DD (FADD), which then binds two procapase-8 molecules, forming the death-inducing signaling complex (DISC). Dimerization of procaspase8 causes activation of capase 8 via auto-proteolytic cleavage. Downstream caspases are then activated either directly (type I) or via mitochondrial perturbation (type II), each resulting in apoptosis (Chinnaiyan et al., 1995; Medema, et al., 1997; Scaffidi, et al., 1998).

Expression of Fas correlated with the degree of apoptosis in human granulosal cells (Kondo et al., 1996). Activation of Fas via Fas-activating antibody promotes apoptosis of granulosal cells and atresia in the rat (Sakamaki et al., 1997). Apoptosis results when TNF- $\alpha$ binds to TNFR-1; however, when it binds to TNFR-2 it has survival/anti-apoptotic actions (Hsu, Xiong, and Goeddel, 1995; Prange-Kiel et al., 2001; Xiao, Asselin, and Tsang, 2002). Finally, TRAIL and its receptor have been indicated to cause apoptosis in granulosal cells based on their levels of expression and activity (Inoue et al., 2003), yet its specific role is unknown.

The Fas/FasL system is the most well-characterized apoptotic signaling pathway in follicles. Based on evidence that FasL and Fas are present in healthy, non-atretic follicles (Inoue et al., 2006), factors blocking the actions of death receptors are purportedly essential for maintaining the health of non-atretic follicles (Matsuda-Minehata et al., 2006). Cellular FADD- 
like interleukin-1 beta-converting enzyme (FLICE)-like inhibitory protein (cFLIP) is an inhibitor of Fas activity and has been found in porcine follicles (Goto et al., 2004) and was shown to be high in healthy follicles and to decrease during atresia (Matsuda-Minehata et al., 2005). Transfection of a human ovarian granulosal tumor cell line (Nishi et al., 2001) or a porcine derived line (Chedrese et. al., 1998) with pcFLIP reduced apoptosis of the cells compared to those treated with an empty vector.

\section{F. Ovulation Rate}

Ovulation rate, the first factor limiting litter size, is determined by complex interactions between survival and apoptotic mechanisms during emergence and selection. In cattle, the cohort begins with 10-50 follicles during each wave, and superovulation protocols have demonstrated that all of these follicles are capable of ovulation (Breuel et al., 1991). Despite this, the incidence of multiple ovulations is rare (Ginther et al., 2001). The follicle that will be selected cannot be identified beforehand, making studies examining selection difficult. However, there are several phenomena through which insights can be gained.

\section{Compensatory Hypertrophy}

Sir John Hunter (1787) reported that removing one ovary from a gilt did not reduce the size of subsequent litters. This experiment, which used only one animal, was the first to highlight a phenomenon now known as compensatory hypertrophy. This ability for one ovary to compensate and maintain the ovulation rate of two ovaries has been demonstrated in the rat (Mandl and Zuckerman, 1951), hamster (Greenwald, 1961), pig (Brinkley, 1964) and ewe (Mallampati and Casida, 1970). In hamsters, ovulation rate did not change following unilateral ovariectomy (ULO) in 14 subsequent estrous cycles, but this compensation could be blocked by estradiol cyclopentylpropionate. Conversely, progesterone was unable to block compensation, 
but instead lengthened the estrous cycle. Similarly, hemi-spayed rats showed full compensation for 10 cycles, before ovulation rate was reduced to six to eight ovulations per cycle (Chatterjee and Greenwald, 1972), which was still greater than the normal ovulation rate of one ovary. Similar lines of evidence led Lipschutz (1928) to formulate his "Law of Follicular Constancy," which states, "[T] ne number of ova entering into follicular development, the rhythm of follicular development and the degree which is attained by follicular development are constant and are controlled by somatic factors outside the ovary."

Removing one ovary on different days of the estrous cycle has been used to determine how late in the cycle compensation can occur. Pigs compensated fully when ULO was performed on days 12,14 , and 16 of the estrous cycle, but ULO on day 16 of the cycle also lengthened the estrous cycle. Performing ULO on day 18 in gilts led to partial compensation, and compensation at the next estrus was totally lost by day 19 (Coleman, Fleming, and Dailey, 1984). Findlay and Cumming (1977) performed ULOs on day 14 and 16 of the ovine estrous cycle during the breeding season. Compensation was complete when ULO was performed on day 14 but incomplete when performed on day 16. Taken together, these results (Findlay and Cumming, 1977, Coleman, Fleming, and Dailey, 1984) indicate that selection can occur late in the estrous cycle. The follicular wave of origin of the ovulatory follicles was unaccounted for in either study, but it is assumed the results are due to selection of potentially atretic follicles. Following cauterization of all visible follicles on the porcine ovary, six days were required to produce ovulatory follicles (Dailey et al., 1976), which is longer than the interval from surgery to ovulation in Coleman's study.

After ULO, species that have single-ovulations compensate by continuing to ovulate one follicle each cycle. Coupled with the fact that relatively large follicles can be tracked via 
ultrasonography and the fact that follicular dynamics have been well characterized, cows make an ideal model to study compensation. Because ULO is associated with higher concentrations of FSH and more similar sizes of the two largest follicles at estrus (Saiduddin, Rowe, and Casida, 1970), Merz (1977) tried to induce double ovulations using ULO on day 13 or 14 and injections of hCG at the onset of estrus. The number of CL after the next estrus was not affected. In contrast, ULO the day after ovulation resulted in an abnormally high number of cows ovulating multiple follicles (4 of 6) following the next natural luteolysis (Mohan and Rajamahendran, 1997). Based on ultrasonographic data, they concluded that growth dynamics of the follicles or hormonal concentrations (FSH, LH, and progesterone) did not differ following ULO, but the wave from which the ovulatory follicles originated was not addressed.

\section{Prolific Sheep Strains}

Intensive screening and selection of Merino ewes in New Zealand led to development of a strain of highly prolific sheep called Booroola Merino (Piper and Bindon, 1982). A genetic basis for this prolificacy quickly became apparent with increased ovulation rate being inherited in a Mendelian manner (Davis et al., 1988). The effect on ovulation rate was additive with an increase in ovulation rate of 1.65 per copy of the mutated gene (Piper, Bindon, and Davis, 1985). The mutation is in the gene encoding bone morphogenetic protein (BMP) receptor $1 \mathrm{~B}$ (Mulsant et al., 2001; Souza et al., 2001).

A similar mechanism is responsible for the increased ovulation rates of Inverdale Romney ewes. In this case the high prolificacy is due to one of two different point mutations in the gene encoding BMP 15 (Galloway et al., 2000). Ewes heterozygous for this mutation $\left(\mathrm{FecX}^{1}\right)$ gene have an increased ovulation rate (Davis et al., 1995). However, homozygous carriers are infertile, apparent from their streak-like ovaries (Davis et al., 1992). 
Therefore, both strains have defects in bone morphogenic protein (BMP)-15 signaling.

The ligand is expressed only by the oocyte, but receptors are found on granulosal cells (Souza et al., 2002), where it has an anti-apoptotic effect (Hussein et al., 2005; Galloway et al., 2000).

So, the reduced BMP-15 signaling results in fewer granulosal cells per follicle, as evidenced by the smaller follicles in these strains. Yet coupled with the higher ovulation rate, the combined number of granulosal cells present in ovulatory follicles and the total ovarian estradiol secretion is similar to wildtype ewes (Baird et al., 1982). This can be interpreted as follicles being continually selected until a threshold concentration of estrogen is reached. If this interpretation is correct, then aromatase is key to determining a follicle's fate.

\section{M athematical M odels}

A mathematical model was proposed to explain how each species accurately controls ovulation rate (Lacker, 1981). This model relied on six basic assumptions for a system consisting of ovaries, a hypothalamic-ovarian (HPO) axis, and a circulatory system. The assumptions are

1. The estrogen secretion rate of a model follicle is a measure of its maturity.

2. The maturation rate of each model follicle at any time depends on its maturity and on the circulating concentrations of FSH, LH, and estrogen.

3. All model follicles are assumed to inherit the same developmental program. More precisely, any two follicles with the same maturity will develop at the same rate when exposed to the same circulating hormone concentrations.

4. The circulating concentration of estrogen at any time is the sum of the contributions made by each follicle.

5. The circulating estrogen concentration regulates the release of FSH and LH from the pituitary-hypothalamic axis. The response of the pituitary-hypothalamus is fast on the time scale of follicle development.

6. Estrogen, FSH, and LH are removed from the circulation at rates that are proportional to their concentration. The half-life of a molecule of 
estrogen, FSH, or LH in the circulation is short on the time scale of follicle development.

Assumption two rests on the idea that a follicle's growth rate depends on its current maturity and hormonal concentrations. Because follicular maturity and hormonal milieu change, the growth or regression of follicles is constantly changing. This idea can be best thought of as a maturation surface with growth or regression rate depicted at each combination of maturation and endocrine environment (Lacker et al., 1987).

The final test for any mathematical model would be to run computer simulations, to judge how closely it can mimic physiological events. By starting the program with follicles of random beginning maturities, surprisingly accurate results were obtained. With the correct maturation table, one follicle was always allowed to continue growth, while all others regressed. While this scenario was very similar to events in single-ovulating species, the program could be adapted to allow a variable and increased number of follicles to proceed to ovulation (Lacker et al., 1987), mimicking litter-bearing species.

Assumption one stated that estrogen secretion rate is a measure of follicular maturity. This assumption is valid, because aromatase expression increases as follicular maturity increases (Bao et al., 1997). However, early in the follicular wave, the dominant inhibitor of FSH secretion is inhibin (Law, 1992). While Lacker's assumptions ignore this, it is not a major caveat. Inhibin is less potent than estradiol and the effect due to inhibin is replaced as subordinate follicles undergo atresia. In other words, this model uses estradiol as a marker of maturity, although it is not the only hormone regulating FSH.

The fourth assumption stated that the concentration of estradiol in the serum is the sum of the contributions of each follicle. While other sources of estradiol exist (adipose tissue and adrenal gland), their contributions are minute and relatively constant compared to changes 
during follicular growth. Thus, this assumption is valid, allowing concentration of estrogen to predict follicle development.

While inhibin and estrogen are thought to be primarily responsible for control of FSH (Rocke and Ireland, 1981; Law, 1992), Lacker's assumptions ignored the role of progesterone in regulating $\mathrm{LH}$. LH is released in a pusatile manner, and the frequency and amplitude of the pulses can be modified so as to affect the overall concentration. Using ovariectomized ewes, Goodman and Karsch (1980) showed that LH pulse amplitude was limited by estradiol. So, estradiol does have an effect on LH. However, progesterone decreased pulse frequency, which was more important for regulating the overall concentration of LH. Stumph et al. (1993) showed a similar response in ovariectomized cows, finding that estradiol reduced LH pulse frequency to a lesser degree than progesterone.

The concentration of progesterone is high and does not change much during the gonadotropin-dependent growth of the ovulatory follicle; therefore, LH pulse frequency changes little. In contrast, the concentration of progesterone during the first follicular wave is increasing but overall it is lower than during the ovulatory wave. The lower concentration of progesterone results in a higher LH pulse frequency. This difference between follicular waves can be viewed as each wave having its own developmental program. During the first wave greater LH pulse frequency results in a higher incidence of two follicles becoming dominant, but during the ovulatory wave in a normal cycle, fewer LH pulses result in fewer cases of double dominance (Kulick et al., 2001).

The second assumption explained that maturation rate depends on the maturity of a follicle and concentrations of gonadotropins. As noted earlier in this review, FSH and LH 
regulate gonadotropin-dependent follicular growth, and the concentrations of gonadotropins change during a follicular wave, therefore, this assumption has a solid physiologic foundation.

The third assumption stated that all follicles of the cohort have the same developmental program. Selection, then, requires only a slight advantage in follicular maturity. While not strictly true, the selected follicle does have a temporal advantage over the subordinate follicles in cows (Ginther et al., 1999), which affects estrogen secretion. Follicles are selected based on their ability to secret estrogen.

III. Statement of Problem

Lacker (1981) and Ginther et al. (1999) concluded that selection of a follicle occurs due to a temporal advantage of that follicle, i.e. the follicle to be selected is more mature than the follicles that become subordinates. However, the expression of many genes and proteins changes with time during follicular selection (Bao et al., 1997; Sudo et al., 2007). Comparisons of selected and subordinate follicles indicate a role for steroidogenic enzymes, components of the IGF system, and gonadotropin receptors in selection. However, the dominant follicle cannot be identified until after selection, so initial changes resulting in dominance remain elusive. Therefore, the objective of this research was to use compensatory hypertrophy in a mono-ovulating species to identify a time in which a subordinate follicle can be induced to become dominant.

IV. M Materials and $M$ ethods

A. Animals

1. Experiment 1

Nulliparous Holstein and Ayrshire heifers (average age of 16 months) were managed as part of the West Virginia University dairy. Animals were kept on an indoor paddock with outside 
access for approximately 10 hours per day. The heifers' estrous cycles were synchronized with a single intramuscular injection of $25 \mathrm{mg}$ of Lutalyse ${ }^{\circledR}$ (Pharmacia and Upjohn Company, NY, NY). Then animals were observed twice daily for estrus, which was designated as day 0. Animals were assigned randomly either to have the largest follicle ablated (as described by Pieterse et al., 1988) on day 17 or 19 of the estrous cycle or to serve as non-ablated controls.

Beginning on day 8, both ovaries were scanned daily with an Aloka SSD-900v scanner (Aloka Co., Wallingford, CT, USA) equipped with a $7.5 \mathrm{MHz}$ transducer. Rectal contents were emptied manually, and the transducer was inserted and rotated until an ovary was located. The approximate maximal diameter of each follicle $\geq 4 \mathrm{~mm}$ and the CL were measured in two dimensions, using the internal calibers, and the average of these two measurements was recorded as the diameter. The location and size of each follicle were used to track follicular growth.

Ablation was carried out as described by Bergfelt, Lightfoot, and Adams (1994) using an Aloka-500 ultrasound (Aloka Co., Wallingford, CT, USA). Caudal epidural anesthesia was induced with $5 \mathrm{ml}$ of $2 \%$ lidocaine, and the vulva was cleaned with iodine. Next, a convex-array transducer, fitted with a plastic handle equipped with a needle guide, was inserted into the vagina. While the transducer was in the area of the vaginal fornix, the free hand was inserted into the rectum and used to position the ovary against the vaginal wall. The follicle to be ablated was positioned against the transducer face. An 18-gauge, 4 inch needle was placed on the needle guide and advanced through the vaginal wall into the follicular antrum. Echogenicity of the needle allowed for determination of location. After the follicle was punctured, the needle was withdrawn and slight pressure was applied to the follicle to expel residual follicular fluid. All procedures for this experiment were approved by the West Virginia University Institutional Animal Care and Use Committee (\# 08-0102). 


\section{Experiment 2}

Mutiparous beef cows of mixed breeding were observed for estrus twice daily. After displaying an estrous cycle of normal length (19-23 days) animals were assigned to be unilaterally ovariectomized on day 13 or 15 post estrus. Ultrasonography was carried out as in experiment 1. Follicular size and location were determined by ultrasonography and recorded every other day from day 9 until ULO, which was carried out via culpotomy (Casida, 1959). Caudal epidural anesthesia was induced with $5 \mathrm{ml}$ of $2 \%$ lidocaine, and the caudal area was scrubbed. A hand was inserted into the vagina, and an incision was made on the dorsal, cranial vaginal surface. The ovary to be removed was brought into the vagina, and the hilus of the ovary was clamped with an ecrasure and the ovary removed. If an ablation and/or enucleation needed to be carried out, the remaining ovary was brought into the vagina. Ablations were carried out by inserting a needle into the vagina and puncturing the desired follicle. Enucleations were done by applying manual pressure around the CL, and removing the CL by blunt dissection. After surgery, the remaining ovary was monitored by ultrasonography every 12 hours for 12.5 days.

When the ULO was performed, one ovary, the CL, and the two largest follicles were removed or destroyed, leaving only subordinate follicles on the in situ ovary. The removed ovary was placed in saline and transported on ice to the laboratory. Within 20 minutes of removal, follicles greater than $5 \mathrm{~mm}$ were dissected from the ovary, trimmed of excess tissue, and snap frozen.

Blood samples were harvested hourly via jugular venipuncture from -1 hour until 12 hours after surgery and then every 12 hours for 12.5 days. Samples were allowed to clot for 12 - 24 hours at $4^{\circ} \mathrm{C}$, centrifuged at 2,000X for 25 minutes, and serum was aspirated, aliquoted, and frozen 
at $-20^{\circ} \mathrm{C}$. All procedures were approved by the West Virginia University Institutional Animal Care and Use Committee (\# 08-1201).

\section{B. Radioimmunoassay}

Concentrations of LH were measured by double antibody radioimmunoassay as previously described and validated (Goodman et al., 2004). Inter- and intra-assay coefficients of variation were $3.77 \%$ and $0.33 \%$ respectively.

\section{Tissue Processing and Real time RT-PCR}

Subordinate follicles were dissected from the ovary, trimmed of extra tissue, snap frozen, and stored at $-80^{\circ} \mathrm{C}$. When follicles were removed from storage, the surface of the follicle was dipped in saline, and 30 seconds later the thecal cells and basal lamina were peeled from the frozen granulosal cells and follicular fluid. Each cell type was centrifuged and the supernatant was discarded. Total mRNA was isolated from granulosa cells using RNAqueous Micro® (Ambion, Applied Biosystems, Foster City, CA), and from the thecal cells using TRIzol® (Life Technologies Carlsbad, California).

Total RNA from each cell type was treated with DNase, and then cDNA was made using Superscript III reverse transcriptase (Invitrogen, CA). Primer sequences were designed based on the corresponding cDNA sequences using Primer3 software (Table 1). Quantitative PCR was performed for each cDNA sample in a Bio-Rad iCycler iQ Real-Time PCR Detection System using $\mathrm{iQ}^{\mathrm{TM}} \mathrm{SYBR}^{\circledR}$ Green Supermix (Bio-Rad, Hercules, CA) in 25- $\mu$ l reaction volumes containing each primer at $300 \mathrm{nM}$ and a cDNA generated from $0.58 \mu \mathrm{g}$ of total RNA. Threshold lines were adjusted to intersect amplification lines in the linear portion of the amplification curve, 
and cycles to threshold $(\mathrm{Ct})$ were recorded. Relative change of mRNA expression was calculated by the $\quad C_{T}$ method (ABI Prism 770 sequence detection system, 2001).

\section{Statistical A nalysis}

Data were analyzed using the Proc Mixed model of SAS®. Ultrasonic data from experiment 1 were analyzed by orthogonal contrasts comparing control to treated groups and day17 to day-19 treated groups. Ultrasonographic data from experiment 2 were analyzed by t-test. Real-time RT PCR data were analyzed using analysis of covariance (Yuan et al., 2006).

V. Results

\section{A. Experiment 1}

Control animals had an estrous cycle with two (5 of 6, Figure 1) or three follicular waves (1 of 6, Figure 2). Ablation of the follicle, regardless of day, significantly increased the number of animals experiencing a third wave (10 of 10, examples in Figure 3 and 4, P $<0.05)$. Day of emergence of the second wave was not different between treatments $(\mathrm{P}>0.1)$.

Overall, the length of the estrous cycle was affected by treatment, with cycle length and the interval from emergence of the second wave to ovulation being 4 days longer in the ablated groups than controls $(\mathrm{P}<0.01$ and $\mathrm{P}<0.001$, respectively), but no differences were observed between ablated groups. Characteristics of the ovulatory follicle (size and growth rate) did not differ between control and treated groups (Table 2).

\section{B. Experiment 2}

Characteristics (day of emergence of the second wave and size of the largest subordinate follicle) of the subordinate follicles on the ovary left in situ were not different between groups. All animals undergoing surgery on day 13 ovulated a subordinate follicle that was present on the ovary 
at the time of ULO (Figure 5). However, none of the animals undergoing surgery on day 15 rescued a subordinate follicle (figure $6, \mathrm{P}<0.01$ ). Growth rates of the ovulatory follicles did not differ. Neither did the day of ovulation differ, as determined by the disappearance of the dominant follicle and subsequent formation of a CL in the same location (Table 3).

Concentration of LH increased gradually over the first 12 hours after surgery $(\mathrm{P}=0.01)$, but there was no effect of treatment and no interaction between treatment and time (Figure 7). Concentrations of $\mathrm{LH}$ in serum samples taken at 12 hour intervals for 12.5 days increased significantly with time $(\mathrm{P}<0.05)$, due to the LH surge occurring 108 - 144 hours post-ULO. Treatment had no effect on concentrations of LH over the 12.5 days, and there was no interaction between time and treatment (Figure 9). When analyzed relative to the time of surgery, time was significant $(\mathrm{P}<0.0001)$, but again there was no effect of treatment or an interaction of time and treatment (Figure 9). No differences were detected in gene expression of any genes investigated in the theca (Table 4). Unfortunately, due to technical difficulties real-time RT- PCR could not be performed on mRNA collected from granulosa.

\section{Discussion}

Confirming earlier reports (Ginther et al., 1989; Ahmad et al., 1997) normal estrous cycles contained two or three waves of follicular growth. The current research showed that a nonselected follicle can be recovered consistently on day 13 post estrus; however, this ability was lost by day 15 . That the day of emergence of the second wave did not differ affirmed the conclusion that removal of the selected follicle induced emergence of a third wave. Ultrasonic observations of the recovered follicles revealed similar patterns of growth as in normally selected follicles, so this model can be used to study follicular selection. 
That early follicular growth does not require FSH support is well established (Edwards et al., 1977). In the cow, this has been shown to end when a follicle reaches $4 \mathrm{~mm}$ in diameter (Gong et al., 1995). At the same time, the recruited follicles are secreting inhibin (Wood, 1992), which suppresses FSH secretion (Gibbons et al., 1997). As concentrations of FSH decline, follicles of the cohort begin to undergo atresia. Eventually, the suppressive effects of inhibin from the entire cohort are replaced by estrogen from a single follicle, in single ovulating species.

The transition to regulation by estrogen is not well understood, but there is evidence that estrogen starts the process. Booroola Merino and Inverdale Romney ewes recruited more follicles into the cohort, yet total estrogen production of all ovulatory follicles is similar to wild-type ewes (Baird et al., 1982). In cows, decreases in estrogen availability delayed deviation, purportedly until concentrations of estrogen were restored. Lacker's (1981) assumptions of identical developmental programs for all follicles and estrogen being a measure of maturity mean that the most mature follicle secretes the most estrogen, and Ginther has shown the selected follicle to be more mature, and thus it should have greater aromatase expression than the follicles that become subordinate (Ginther et al., 1999).

Estrogen increases the sensitivity of emerging follicles to FSH (Richards, 1980). This would allow the first follicle to secrete estrogen to survive the declining concentrations of FSH. Estrogen, a potent inhibitor of FSH secretion, would also prevent follicles less mature and less sensitive to FSH from continuing growth. Most importantly, estrogen in combination with FSH increases transcription of PAPP-A (Sudo et al., 2007). Increased PAPP-A would lead to increased free IGF, which would cause follicular dominance (Ginther et al., 2004), but the pathway is unclear. IGF has three major intrafollicular actions (Figure 9). IGF-I induces estrogen production (Silva and Price, 2002), which would amplify the effects of estrogen. Secondly, IGF stimulates 
angiogenesis, increasing blood flow to the follicle (Grado-Ahuir et al., 2009). Increased blood flow would bring more growth factors to the follicle, including the declining FSH and bound IGF, which would be freed by PAPP-A. IGF also contributes to development of LH receptors, though the signaling mechanism involved is unclear. During this feedback between estrogen and IGF of the second or third successive dominant follicle of an estrous cycle, the CL normally regresses. Loss of progesterone allows estrogen to trigger the LH surge and ovulation proceeds.

In an attempt to explain the loss of ability of a subordinate follicle to assume dominance by day 15, concentrations of LH were analyzed. However, this did not reveal any differences between treatments. The role of estrogen has been studied extensively as it is related to the control of FSH. Following the loss of estrogen production, either after unilateral ovariectomy (Findlay and Cumming, 1977), ablation of all gonadotropin-dependent follicles (Bergfelt et al., 1994; Ginther et al. (2008), or ablation of the dominant follicle (Amiridis et al., 1999) the concentration of FSH consistently rises. Thus, concentrations of FSH would have risen following removal of estrogen negative feedback in the present study.

The current experimental design relied on the assumption that all subordinate follicles are identical and have comparable opportunity to become dominant. This design has the advantage that the follicles used to determine ability to be rescued and the follicles analyzed were from the same animals and were, therefore, genetically identical and exposed to the same hormonal environment, limiting variation. The idea is supported by the ability of any follicle to become dominant after ablation of all follicles larger than it (Ginther et al., 2001), by the finding that the selected follicle's advantage is temporal in nature according to the experimental findings of Ginther et al. (1999) and the assumptions of Lacker's mathematical model (1981). 
Expression of genes controlling steroidogenesis, gonadotropin signaling, and follicular growth was determined in the follicle using real-time RT-RCR. The expression of thecal cell genes did not differ. Due to technical difficulties, real-time RT-PCR on mRNA isolated from granulosal cells could not be performed. This is unfortunate because most models aimed at explaining follicular selection focus on interactions involving the granulosal cells.

Many current medical and agricultural practices alter selection to increase the number of follicles that ovulate by artificially increasing the concentrations of FSH. However, how this changes follicular dynamics in not understood. Therefore, understanding follicular selection and identifying factors that are important for maximizing success are becoming increasingly important. The current model provides a method of studying follicular selection, so that knowledge obtained can be used to maximize offspring borne from super-ovulation protocols. This should facilitate the spread of superior genetics and improve animal agriculture. 


\begin{tabular}{|c|c|c|c|}
\hline Gene Name & Primer Sequence & $\begin{array}{l}\text { Product } \\
\text { Size }\end{array}$ & $\begin{array}{l}\text { Accession } \\
\text { Number }\end{array}$ \\
\hline GAPDH & $\begin{array}{l}\text { F-GTT GTC TCC TGC GAC TTC AAC } \\
\text { R-CCT GTT GCT GTA GCC AAA TTC }\end{array}$ & 129 & NM_001034034 \\
\hline $\begin{array}{l}\text { P450 Side Chain } \\
\text { Cleavage }\end{array}$ & $\begin{array}{l}\text { F-TTA GGA ATT ACC CAG GCA TCC } \\
\text { R-CCA TCT CGT ACA AGT GCC ATT }\end{array}$ & 144 & NM_176644 \\
\hline $\begin{array}{l}\text { Insulin-Like } \\
\text { Growth Factor } 1\end{array}$ & $\begin{array}{l}\text { F- CCT CTG CGG GGC TGA GTT GGT } \\
\text { R- CGA CTT GGC GGG CTT GAG AGG }\end{array}$ & 196 & NM_001077828 \\
\hline $\begin{array}{l}\text { Insulin-Like } \\
\text { Growth Factor } \\
\text { BP-2 }\end{array}$ & $\begin{array}{l}\text { F- GAC AAG CAT GGC CTG TAC AAC } \\
\text { R- AAG AGA TGA CAC TCG GGG TCT }\end{array}$ & 143 & NM_174555 \\
\hline $\begin{array}{l}\text { Insulin-Like } \\
\text { Growth Factor } \\
\text { BP-4 }\end{array}$ & $\begin{array}{l}\text { F- GAA GGG AAG AGG TCA GAG GAA } \\
\text { R- CCT TTC ATC AGG CAC ATA }\end{array}$ & 105 & NM_174557 \\
\hline $\begin{array}{l}\text { Pregnancy } \\
\text { Associated } \\
\text { Plasma Protein-A }\end{array}$ & $\begin{array}{l}\text { F- GAT GTT GAG CAG CCC TGT AAG } \\
\text { R-AGA CTC AGG AAC GGG CTA }\end{array}$ & 144 & XM_613511 \\
\hline LH Receptor & $\begin{array}{l}\text { F- TGA CCA TGG CCC GTC TAA AA } \\
\text { R- TAC TAC CCA AAG CAA TTT ATA } \\
\text { GAT TCA ATG }\end{array}$ & 91 & NM_174381 \\
\hline
\end{tabular}

Table 1. Genes' name, primer sequence, product size and accession number of genes examined in thecal cells. 


\begin{tabular}{cccccc}
\hline \multirow{2}{*}{ Endpoint } & \multicolumn{3}{c}{ M ean \pm S.E. } & \multicolumn{2}{c}{ Contrasts (P value) } \\
\cline { 2 - 6 } Number of waves & $\begin{array}{c}\text { Control } \\
(\mathrm{n}=6)\end{array}$ & $\begin{array}{c}\text { Day 17 } \\
(\mathrm{n}=5)\end{array}$ & $\begin{array}{c}\text { Day 19 } \\
(\mathrm{n}=5)\end{array}$ & $\begin{array}{c}\text { Control vs } \\
\text { Treated }\end{array}$ & $\begin{array}{c}\text { Day 17 } \\
\text { vs 19 }\end{array}$ \\
\cline { 2 - 6 }
\end{tabular}

\begin{tabular}{|cccccc}
\hline E mergence of second wave (day) & $11.00 \pm 0.85$ & $10.40 \pm 0.40$ & $11.20 \pm 0.74$ & 0.8196 & 0.46 \\
\hline Emergence of third wave (day) & $\begin{array}{c}14 \\
(\mathrm{n}=1)\end{array}$ & $17.80 \pm 0.85$ & $19.90 \pm 0.83$ & NA & 0.34
\end{tabular}
Cycle length (days)
$\begin{array}{lllll}19.16 \pm 0.48 & 22.8 \pm 0.92 & 23.40 \pm 0.68 & 0.0004 & 0.56\end{array}$

I nterval- emergence of second

$\begin{array}{lllll}8.17 \pm 0.91 & 12.40 \pm 0.68 & 12.20 \pm 0.80 & 0.0010 & 0.87\end{array}$ wave to ovulation (days)

$\begin{array}{cccccc}\begin{array}{c}\text { Interval- emergence of third } \\ \text { wave to ovulation }\end{array} & \begin{array}{c}7 \\ (\mathrm{n}=1)\end{array} & 5.50 \pm 0.29 & 4.40 \pm 0.24 & \text { NA } & 0.02 \\ \begin{array}{c}\text { Size of largest subordinate } \\ \text { follicle at time of ablation or on } \\ \text { day } 18 \text { in control animals (mm) }\end{array} & 5.1 \pm 0.6 & 5.6 \pm 0.3 & 6.0 \pm 0.5 & 0.23 & 0.58 \\ \begin{array}{c}\text { Size of ovulatory follicle at last } \\ \text { ultrasound before ovulation* } \\ \text { (mm) }\end{array} & 11.73 \pm 0.51 & 11.51 \pm 1.03 & 11.96 \pm 0.41 & 1.0 & 0.66 \\ \begin{array}{c}\text { Growth Rate (mm/day) } \\ \text { G }\end{array} & 1.11 \pm 0.15 & 1.18 \pm 0.29 & 1.50 \pm 0.17 & 0.38 & 0.32\end{array}$

Table 2. Characteristics of estr ous cycles and follicles following ablation of the dominant follicle.

*Ovulation was deduced as disappearance of a large follicle at next ultrasonography. 


\begin{tabular}{|c|c|c|c|}
\hline \multirow[t]{2}{*}{ Endpoint } & \multicolumn{2}{|c|}{ Means \pm S.E. } & \multirow[t]{2}{*}{$P$ value } \\
\hline & Day 13 & Day 15 & \\
\hline Number of waves & $2.00 \pm 0.00$ & $3.00 \pm 0.00$ & $<0.05$ \\
\hline $\begin{array}{l}\text { Emergence of second wave } \\
\text { (day) }\end{array}$ & $11.00 \pm 0.41$ & $11.20 \pm 0.49$ & 0.77 \\
\hline Cycle length (days) & $22 \pm 0.00$ & $22 \pm 0.45$ & 0.41 \\
\hline $\begin{array}{c}\text { Interval- emer gence of } \\
\text { second wave to ovulation } \\
\text { (days) }\end{array}$ & $9.67 \pm 0.58$ & $7.00 \pm 0.45$ & 0.01 \\
\hline $\begin{array}{l}\text { Size of L argest Subor dinate } \\
\text { Follicle L eft I } n \text { Situ (mm) }\end{array}$ & $5.41 \pm 0.40$ & $5.79 \pm 0.51$ & 0.59 \\
\hline $\begin{array}{c}\text { Size of Ovulatory Follicle } 12 \\
\text { hours before ovulation* } \\
(\mathrm{mm})\end{array}$ & $12.0 \pm 0.4$ & $11.8 \pm 0.9$ & 0.89 \\
\hline Growth Rate (mm/day) & $1.66 \pm 0.19$ & $1.99 \pm 0.28$ & 0.39 \\
\hline
\end{tabular}

Table 3. Characteristics of estr ous cycles and follicles following unilateral ovariectomy. *Ovulation was deduced as disappearance of a large follicle by next ultrasonography. 


\begin{tabular}{|lcc|}
\hline Gene & $\begin{array}{c}\text { Fold Difference } \\
\text { (Day 15 relative to Day 13) }\end{array}$ & P Value \\
\hline PAPP-A & 4.07 & 0.94 \\
\hline P450 scc & 2.34 & 0.62 \\
\hline IGF-I & 2.14 & 0.12 \\
\hline IGF-BP 2 & 4.29 & 0.98 \\
\hline IGF-BP 4 & 1.62 & 0.59 \\
\hline L HR & 3.31 & 0.89 \\
\hline
\end{tabular}

Table 4. Results of real-time RT PCR from mRNA harvested from thecal cells. 


\section{Figures}

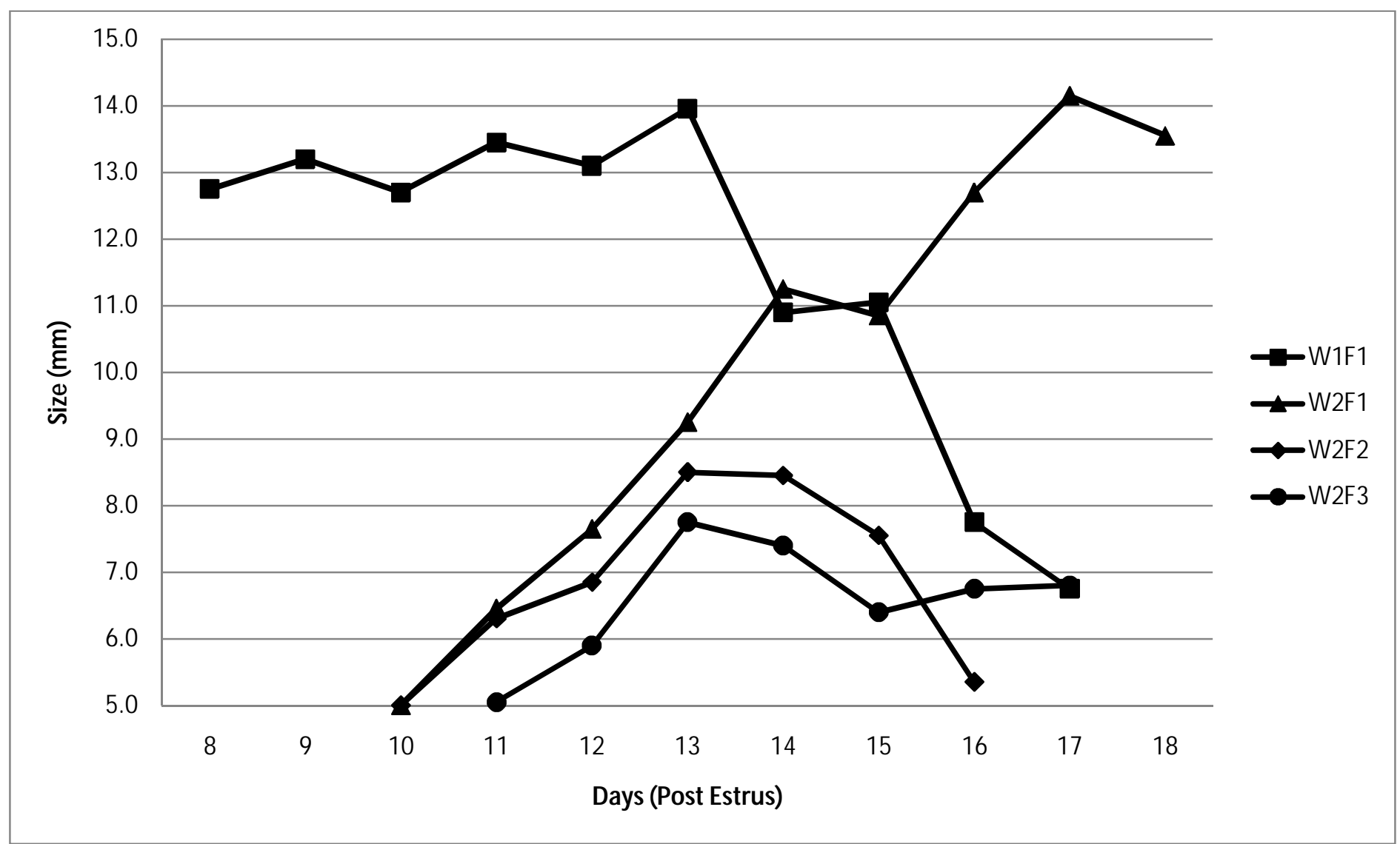

Figure 1. Example of two follicular waves in a control cow. *W represents the follicular wave and $\mathrm{F}$ represents the ranking of the follicle within each wave. 


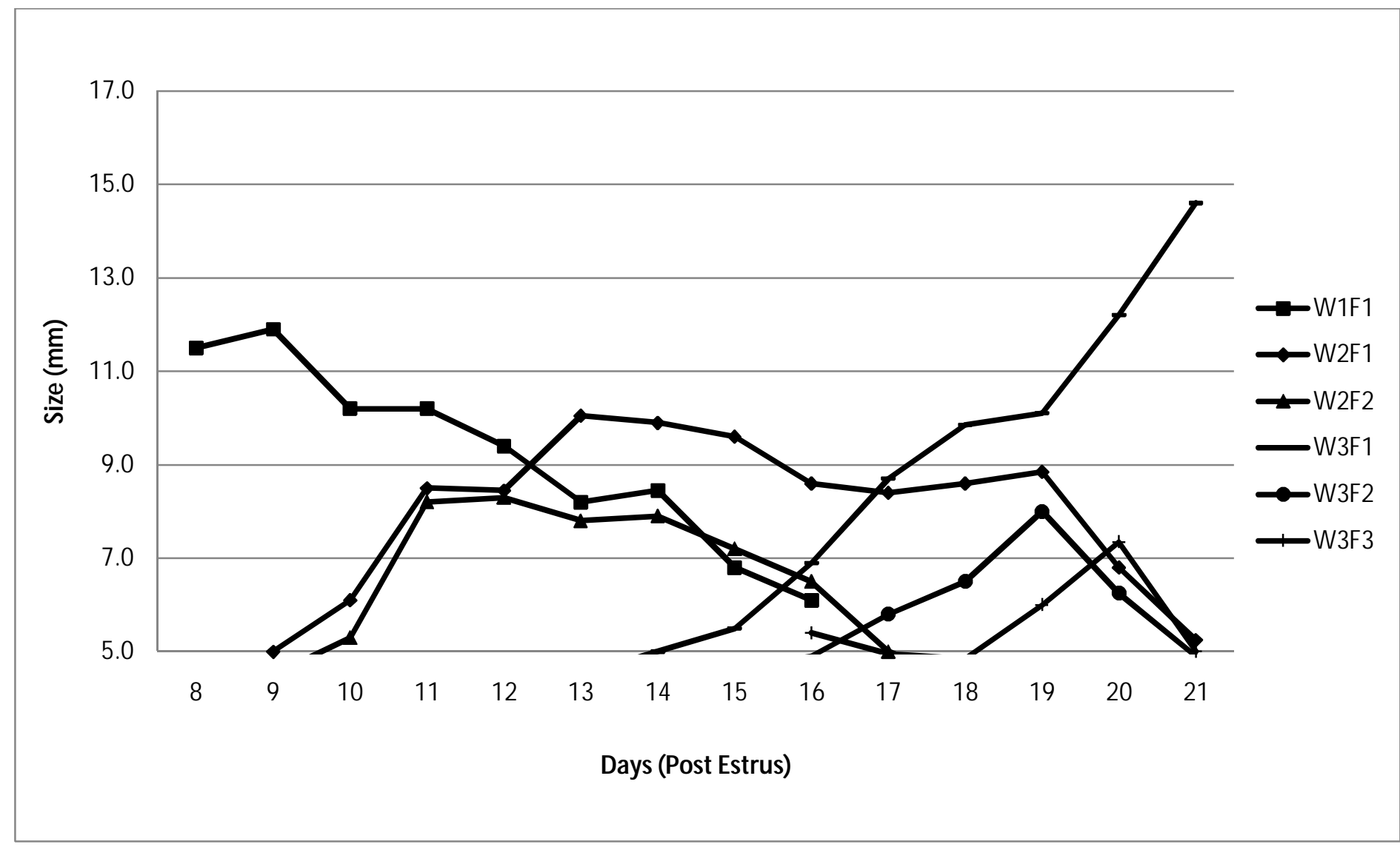

Figure 2. Example of three follicular waves in a control cow. *W represents the follicular wave and F represents the ranking of the follicle within each wave. 


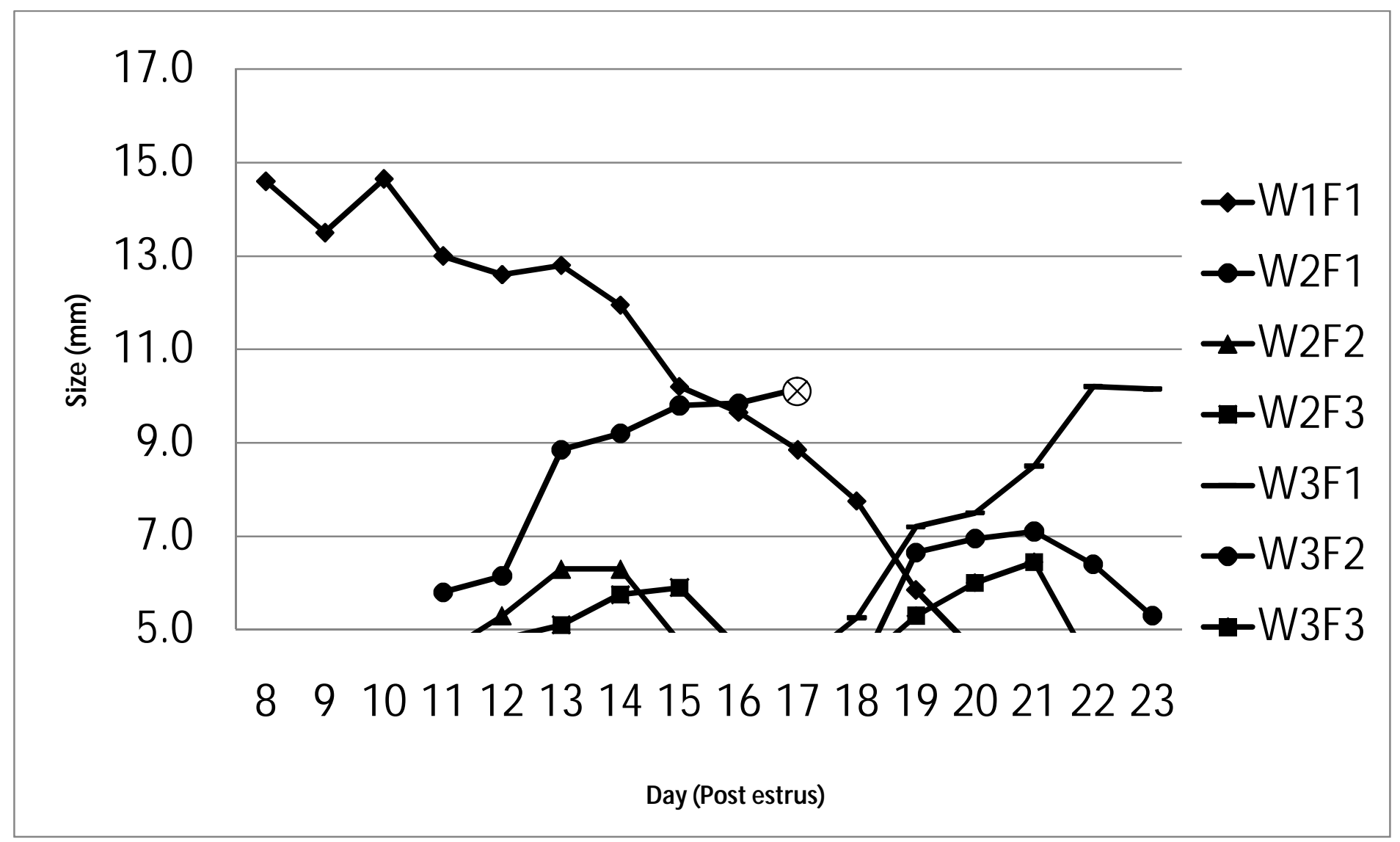

Figure 3. Example of induction of a third follicular wave following ablation of the dominant follicle on day 17 . *W represents the follicular wave and F represents the ranking of the follicle within each wave. $\otimes$ Represents ablation. 


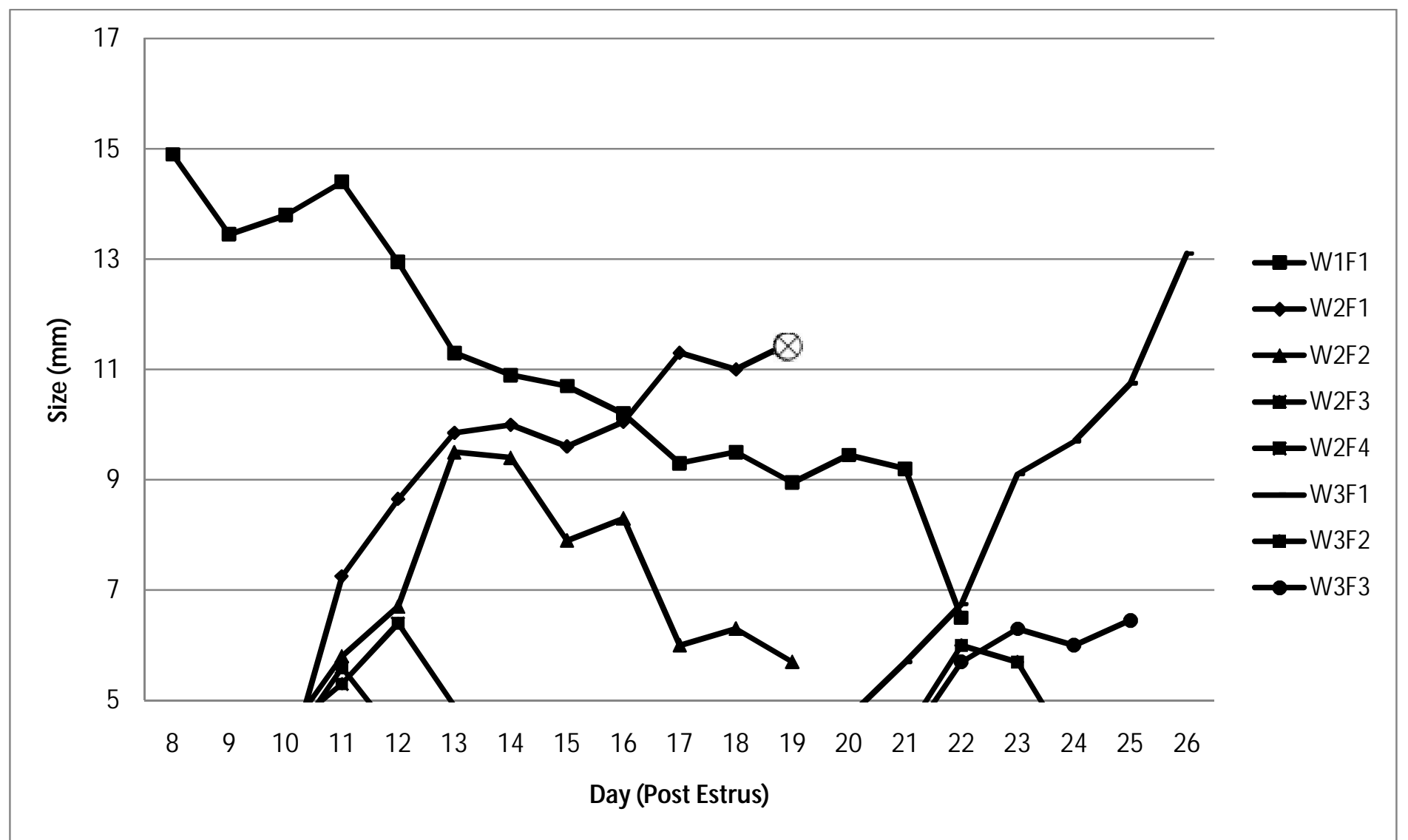

Figure 4. Example of Induction of a third follicular wave following ablation of the dominant follicle on day 19 . *W represents the follicular wave and F represents the ranking of the follicle within each wave. $\otimes$ Represents ablation. 


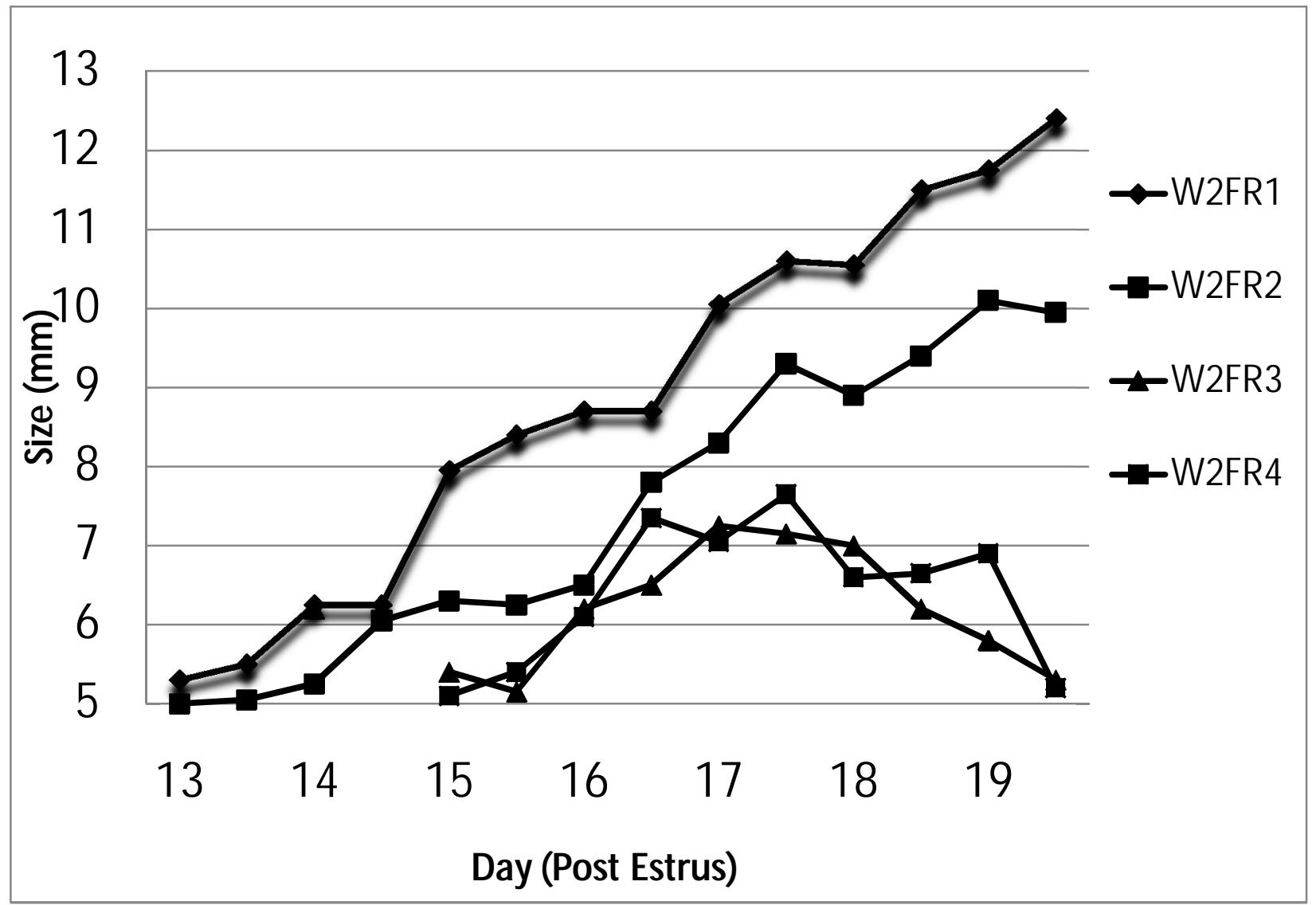

Figure 5. Growth of subordinate follicles foll owing unilateral ovariectomy on day 13 . *W represents wave, FR is follicle remaining after ULO. 


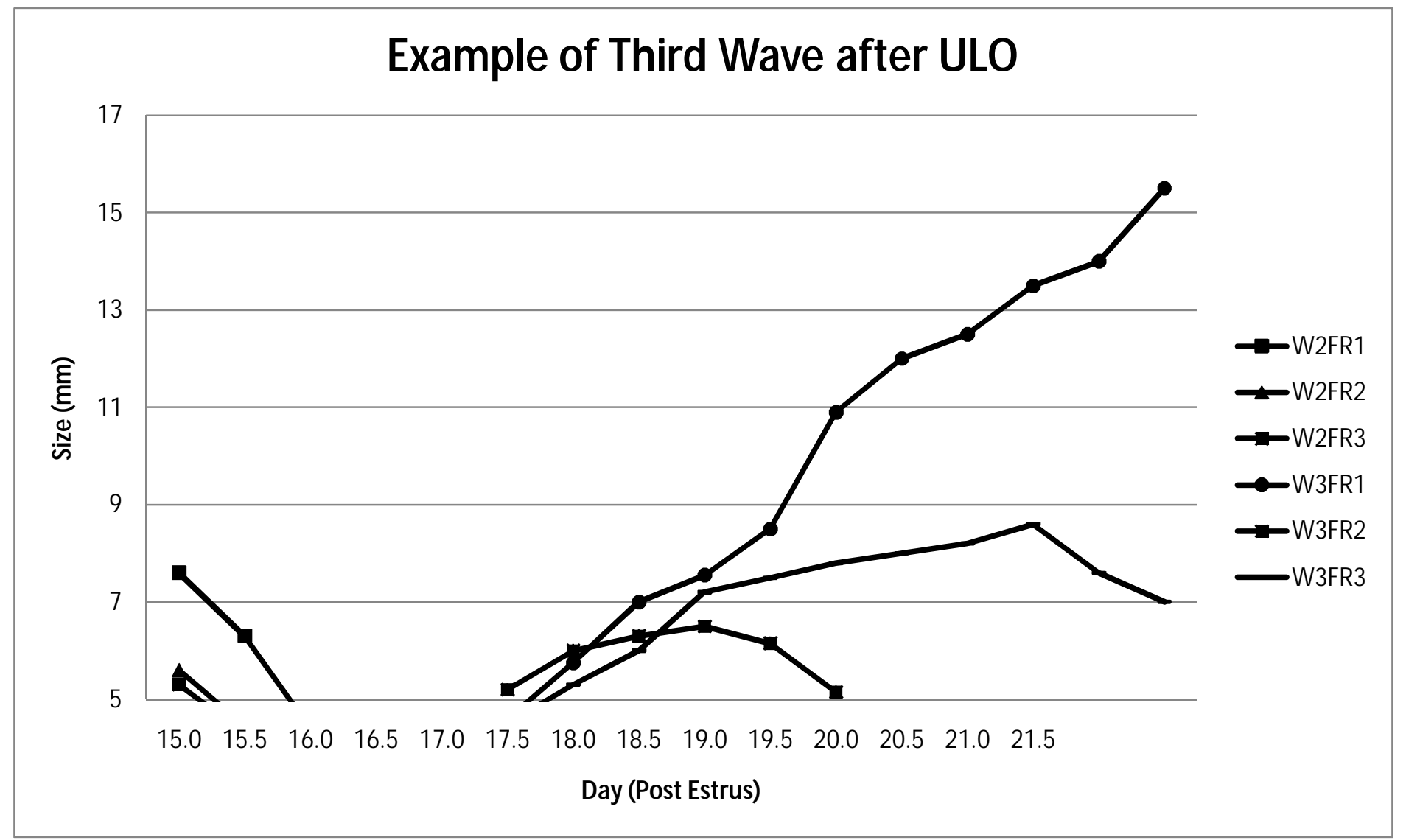

Figure 6. G rowth of subor dinate follicles following unilateral ovariectomy on day 15 . *W represents wave, FR is follicle remaining after ULO. 


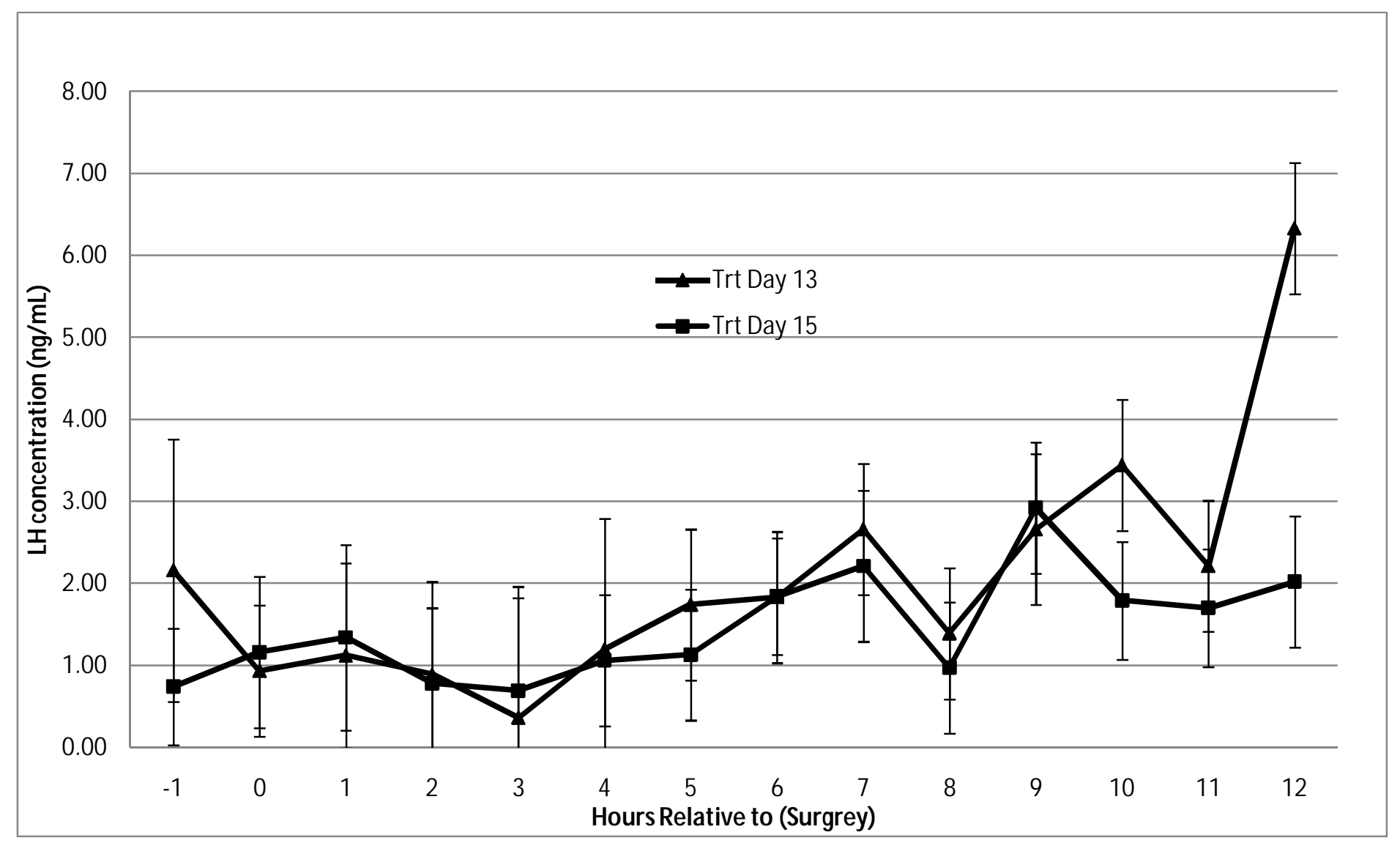

Figure 7. Concentrations of $L H$ for the first 12 hours after surgery. 


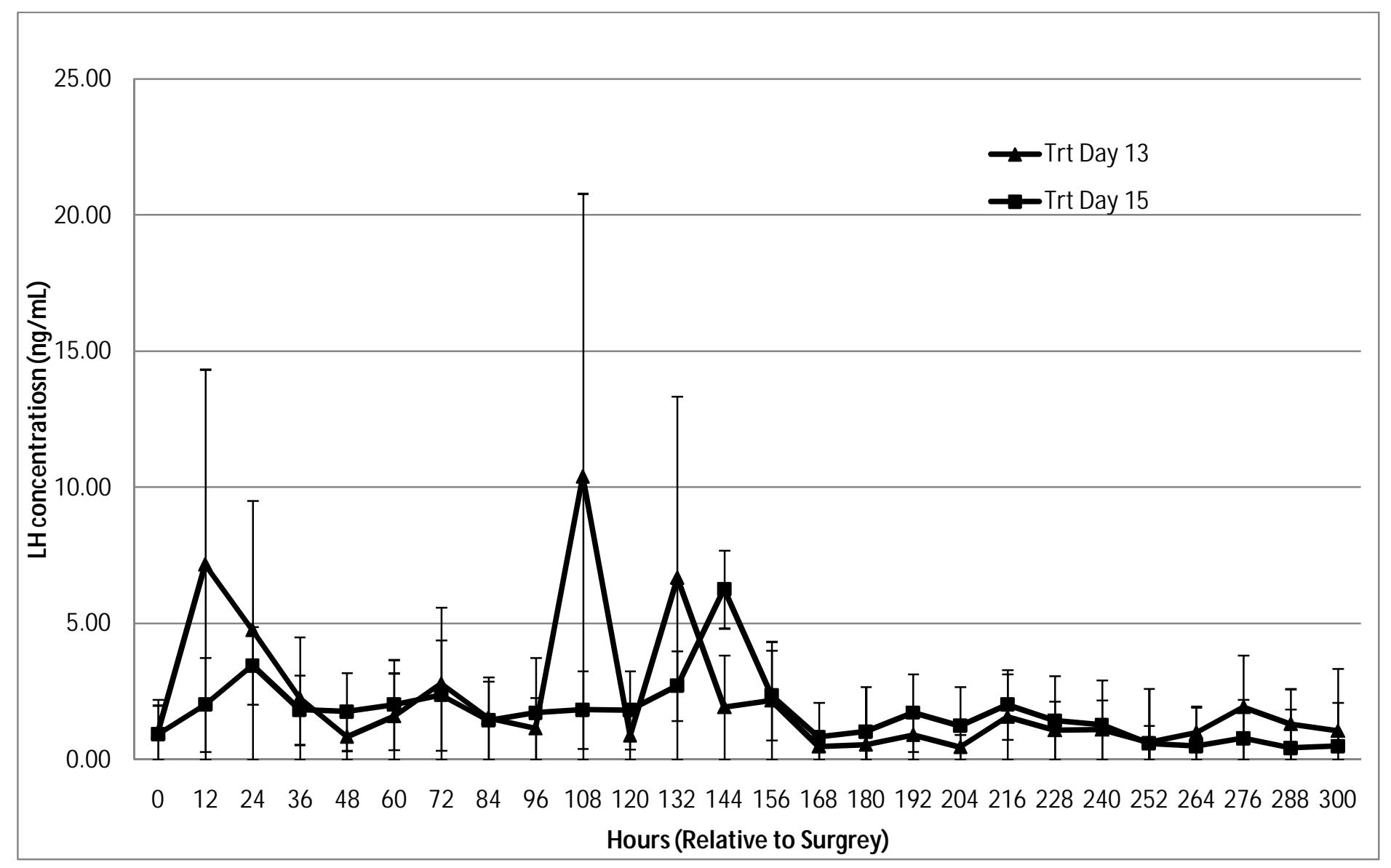

Figure 8. Concentrations of L H for 300 hours post surgery. 


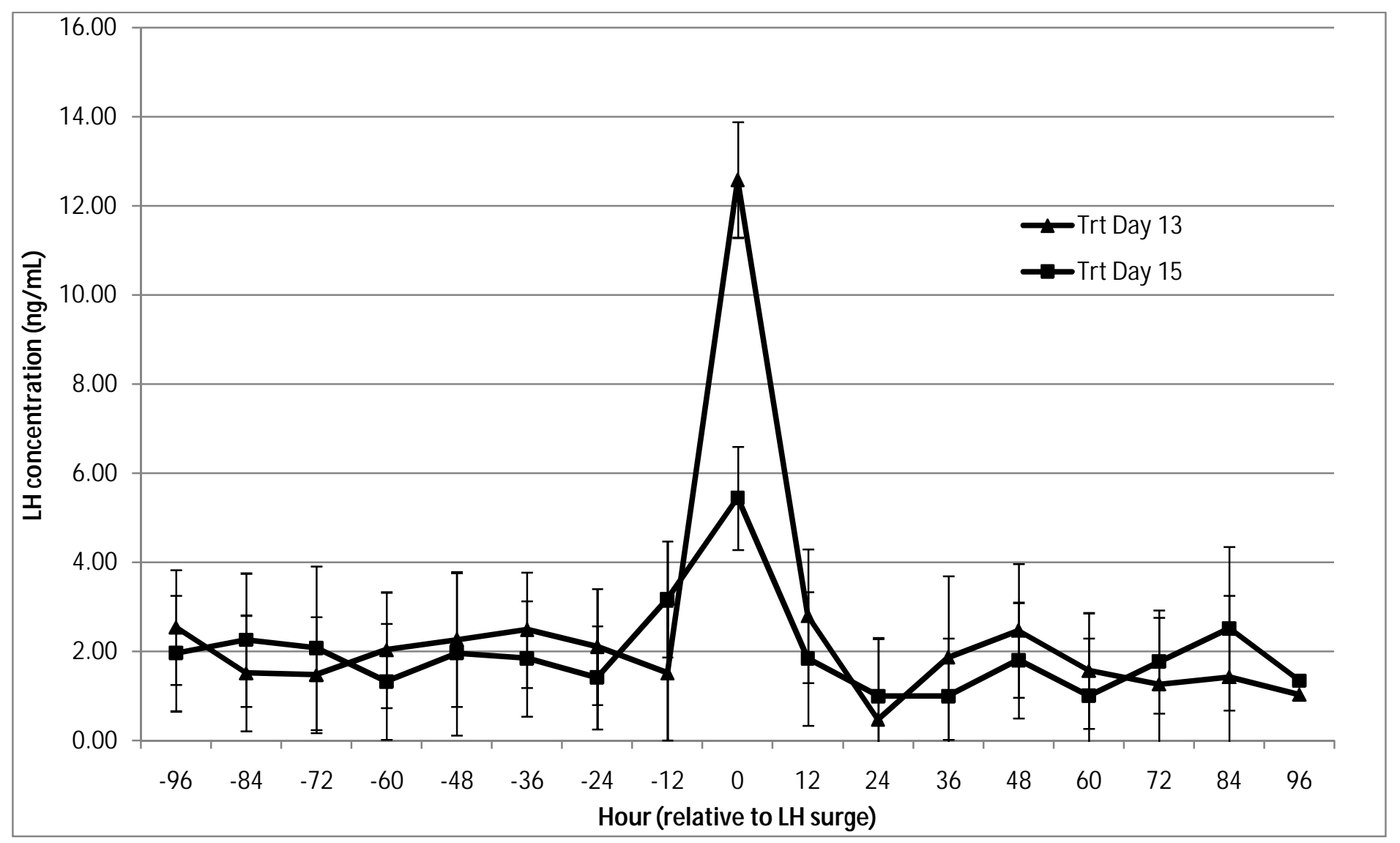

Figure 9. Concentrations of $\mathrm{LH}$ relative to the time of the $\mathrm{LH}$ surge. 


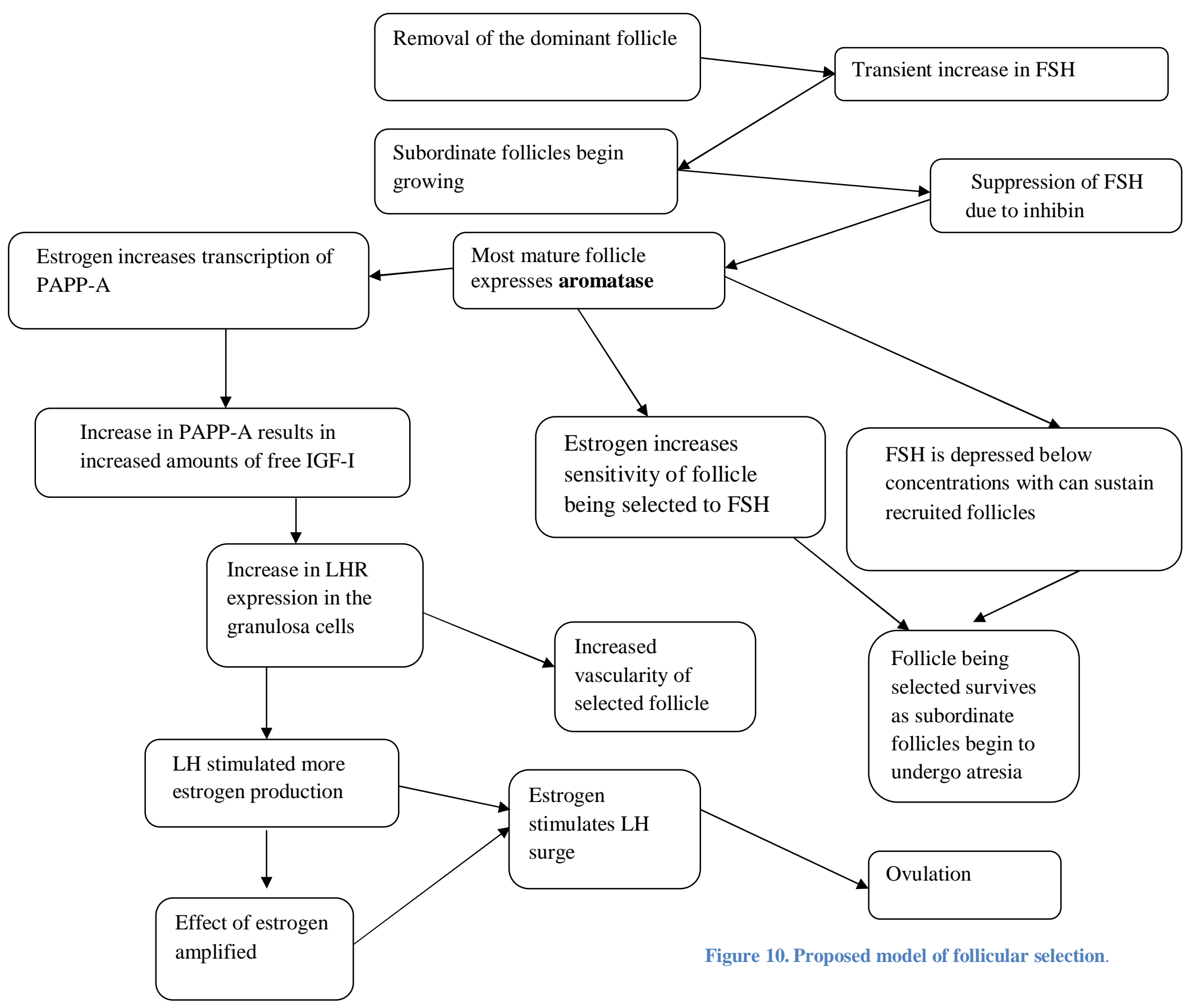




\section{Bibliography}

Aad, P. Y., Voge, J. L., Santiago, C. A., Malayer, J. R., and Spicer, L. J. (2006). Real-time RTPCR quantification of pregnancy-associated plasma protein-A mRNA abundance in bovine granulosa and theca cells: Effects of hormones in vitro. Domest. Anim. Endcrinol., 31(4): 357372.

ABI Prism 770 sequence detection system. (2001). U ser Bulletin \#2. Applied Biosystems.

Adams, G. P., Matteri, R. L., Kastelic, J. P., Ko, J. C., and Ginther, O. J. (1992). Association between surges of follicle-stimulating hormone and the emergence of follicular waves in heifers. J. Reprod. Fert., 94: 177-188.

Ahmad, N., Townsend, E. C., Dailey, R. A., and Inskeep, E. K. (1997). Relationship of hormonal patterns and fertility to occurence of two or three waves of ovarian follicles, before and after breeding, in beef cows and heifers. Anim. Reprod. Sci., 49: 13-28.

Amiridis, G. S., Robertson, L., Boyd, J. S., O'Shaughnessy, P. J., and Jeffcoate, I. A. (1999). Plasma estradiol, FSH, and LH concentration after dominant follicle aspiration in the cow. Theriogenology, 52: 995-1003.

Baird, D. T., Ralph, M. M., and Seamark, R. F. (1982). Pre-ovulatory follicular activity and oestrogen secretion of high (Booroola) and low fecundity Merino ewes. Proc. Australian Soc. Reprod. Biol. 14, Abstract 84.

Baker, T. G. (1963). A quantitative and cytological study of germ cells in human ovaries. Proc. R., Soc. London Ser. B, 158: 417-433.

Bao, B., Garverick, A., Smith, G. W., Smith, M. F., Salfen, B. E., and Youngquist, R. S. (1997). Changes in messenger ribonucleic acid encoding luteinizing hormone receptor, cytochrome P450-side chain cleavage, and aromatase are associated with recruitment and selection of bovine ovarian follicles. Biol. Reprod., 56: 1158-1168.

Beg, M. A., Bergfelt, D. R., Kot, K., and Ginther, O. J. (2002). Follicle selection in cattle: dynamics of follicular fluid factors during development of follicle dominance. Biol. Reprod., 66: $120-126$.

Beg, M. A., Meira, C., Bergfelt, D. R., and Ginther, O. J. (2003). Role of oestradiol in growth of follicles and follicle deviation in heifers. Reproduction, 125(6): 847-854.

Bergfelt, D. R., Lightfoot, K. C., and Adams, G. P. (1994). Ovarian synchronization following utrasound-guided transvaginal follicle ablation in heifers. Theriogenology, 42: 895-907. 
Blandau, J. (1967). Anatomy of ovulation. Clin. O bstet. G ynec., 10: 347-360.

Bodensteiner, K. J., Wiltbank, M. C., Bergfelt, D. R., and Ginther, O. J. (1996). Alterations in follicular estradiol and gonadotropin receptors during development of bovine antral follicles. Theriogenology, 45: 499-512.

Boldt, H. B., and Conover, C. A. (2007). Pregnancy-associated plasma protein-A (PAPP-A): A local regulator of IGF bioavailabilty through cleavage of IGFBPs. G rowth Hormone and IG F Research, 17\&1): 10-18.

Braw-Tal, R., and Yossefi, S. (1997). Studies in vivo and in vitro on the initiation of follicle growth in the bovine ovary. J. Reprod. Fertil., 109: 165-171.

Breuel, K. F., Baker, R. D., Butcher, R. L., Townsend, E. C., Inskeep, E. K., Dailey, R. A., and Lerner S.P. (1991). Effects of breed, age of donor and dosage of follicle stimulating hormone on the superovulatory response of beef cows. Theriogenology, 36(2): 241-255.

Bridges, P. J., and Fortune, J. E. (2007). Regulation, action and transport of prostaglandins during the periovulatory period in cattle. Mol. Cell. Endocrinol., 263(1-2): 1-9.

Bridges, P. J., Komar, C. M., and Fortune, J. E. (2006). Gonadotropin-induced expression of messenger ribonucleic acid for cyclooxygenase- 2 and production of prostaglandins $\mathrm{E}$ and F2alpha in bovine perovulatory follicles are regulated by the progesterone receptor. Endocrinology, 147(10): 13-22.

Brinkley, H. J., Wickersham E.W., and Casida L.E. (1964). Effect of unilateral ovariectomy on the structure and function of corpora lutea of the pig. Endocrinology, 74: 462-467.

Burns, D. S., Jimenez-Krassel, F., Ireland, J. L., Knight, P. G., and Ireland, J. J. (2005). Number of antral follicles during follicular waves in cattle: evidence of high variation among animals, very high repeatability in individuals, and an inverse association with serum follicle-stimulating hormone concentrations. Biol. Reprod., 73: 54-62.

Campbell, B. K., Dobson, H., Baird, D. T., and Scaramuzzi, R. J. (1999). Examination of the relative roles of FSH and LH in the mechanism of ovulatory selection in sheep. J. Repod. Fertil., 117: 355-376.

Casida, L. E. (1959). Research techniques in physiology of reproduction in the female. In Techniques and procedures in animal production research (pp. 106-121). Beltsville: American Society of Animal Production.

Chatterjee, A. and Greenwald, G. S. (1972). The long-term effects of unilateral ovariectomy of the cycling hamster and rat. Biol. Reprod., 7: 238-246. 
Chedrese, P. J., Rodway, M. R., Swan, C. L., and Gillio-Meina, C. (1998). Establishment of a stable steroidogenic porcine granulosa cell line. J. M ol. Endocrinol., 20: 287-292.

Chinnaiyan, A. M., O'Rourke, K., Tewari, M., and Dixit, V. M. (1995). FADD, a novel death domain-containing protein, interacts with the death domain of Fas and initiates apoptosis. Cell, 81: 505-512.

Choudary, J. B., Gier, H. T., and Marion, G. B. (1968). Cyclic changes in bovine vesicular follicles. J. Anim. Sci., 27: 468-471.

Coleman, D. A., Fleming, M. W., and Dailey, R. A. (1984). Factors affecting ovarian compensation after unilateral ovariectomy in gilts. J. Anim. Sci., 59: 170-176.

Concise $0 x f o r d$ American Dictionary. (2006). New York: Oxford University Press.

Dailey, R. A., Clark, J. R., Staigmiller, R. B., First, N. L., Chapman, A. B., and Casida, L. E. (1976). Growth of new follicles following electrocautery in four genetic groups of swine. J . Anim. Sci., 43: 175-183.

Davis, G. H., McEwan, J. C., Fennessy, P. F., and Dodds, K. G. (1995). Discovery of the inverdale gene (FecX). Proc. of the NZ Society of Anim. Prod., 55: 289-290.

Davis, G. H., McEwan, J. C., Fennessy, P. F., Dodds, K. G., McNatty, K. P., and WS, O. (1992). Infertility due to bilateral ovarian hypoplasia in sheep homozygous (FecX1 FecX1) for the inverdale prolificacy gene located on the X chromosome. Biol. Reprod., 46: 636-640.

Davis, G. H., Shackell, G. H., Kyle, S. E., Farquhar, P. A., McEwan, J. C., and Fennessy, P. F. (1988). High prolificacy in screened Romney family line. Proc Aust. Assn. Anim Breed Genet., 7: 406-406.

Donaldson, L., and Hansel, W. (1972). Identification of the ovulation follicle by its size on different days of the estrous cycle in heifers. J. Anim. Sci., 34: 85-87.

Dufour, J., Whitmore, H. L., Ginther, O. J., and Casida, L. E. (1972). Identification of the ovulating follicle by its size on different days of the estrous cycle in heifers. J. Anim. Sci., 34: 85-87.

Edwards, R. G., Fowler, R. E., Gore-Langton, R. E., Gosden, R. G., Jones, E. C., Jones, E. C., Readhead C., and Steptoe P.C. (1977). Normal and abnormal follicular growth in mouse, rat and human ovaries. J. Reprod. Fertil., 51: 237-263.

Elgin, R. G., Busby, W. H., and Clemmons, D. R. (1987). An insulin-like growth factor (IGF) binding protein enhances the biologic response to IGF-I. Proc. Natl. Acad. Sci., 84: 3254-3259. 
Espey, L. L. (1978). Ovarian contractility and its relationship to ovulation: a review. Biol. Reprod., 19: 540-551.

Espey, L. L. (1974). Ovarian proteolytic enzymes and ovulation. Biol. Repord., 10: 216-235.

Espey, L. L. (1980). Ovulation as an inflammatory reaction- a hypothesis. Biol. Reprod., 22: 73106.

Espey, L. L., Coons, P. J., Marsh, J. M., and LeMaire, W. J. (1981). Effects of indomethacin on preovulatory changes in the ultrastructure of rabbit Graafian follicles. Endocrinology, 108(3): 1040-1048.

Findlay, J. K. (1993). An update on the roles of inhibin, activin, and follistatin as local regulators of folliculogenesis. Biol. Reprod., 48: 15-23.

Findlay, J. K., and Cumming, I. A. (1977). The effect of unilateral ovariectomy on plasma gonadotropin levels, estrus and ovulation rate in the sheep. Biol. Reprod., 17: 178-183.

Fortune, J. E. (2003). The early stages of follicular development: activation of primordial follicles and growth of preantral follicles. Anim. Reprod. Sci., 78: 135-163.

Fortune, J. E., Rivera, G. M., and Yang, M. Y. (2004). Follicular development: the role of the follicular microenvironment in selection of the dominant follicle. Anim. Reprod. Sci., 82-82: 109-126.

Fortune, J. E., Sirois, J., and Quirk, S. M. (1988). The growth and differentiation of ovarian follicles during the bovine estrous cycle. Theriogenology, 29: 95-109.

Galloway, S. M., McNatty, K. P., Cambridge, L. M., Laitinen, M. P., Juengel, J. L., Jokiranta, T. S., McLaren, R.J., Luiro, K., Doods, K.G., Montgomery, G.W., Beattie, A.E., Davis, G.H., and Ritvos, O. (2000). Mutations in an oocyte-derived growth factor gene (BMO15) cause increased ovulation rate and infertility in a dosage-sensitive manner. Nature Genetics, 25: 279283.

Gibbons, J. R., Wiltbank, M. C., and Ginther, O. J. (1997). Functional interrelationships between follicles greater than $4 \mathrm{~mm}$ and the follicle-stimulating hormone surge in heifers. Biol. Reprod., 57: 1066-1073.

Ginther, O. J., Bergfelt, D. R., Beg, M. A., and Kot, K. (2001). Follicle selection in cattle: relationship among growth rate, diameter ranking, and capacity for dominance. Biol. Reprod., 65: 345-350.

Ginther, O. J., Bergfelt, D. R., Beg, M. A., Meira, C., and Kot, K. (2004). In vivo effects of an intrafollicular injection of insulin-like growth factor-1 on the mechanism of follicle deviation in heifers and mares. Biol. Reprod., 70: 99-105. 
Ginther, O. J., Bergfelt, D. R., Kulick, L. J., and Kot, K. (1999). Selection of the dominant follicle in cattle: establishment of follicle deviation in less than 8 hours through depression of FSH concentrations. Theriogenology, 52: 1079-1093.

Ginther, O. J., Bergfelt, D. R., Kulick, L. J., and Kot, K. (2000). Selection of the dominant follicle in cattle: role of two-way functional coupling between follicle-stimulating hormone and the follicle. Biol. Reprod., 62: 920-927.

Ginther, O. J., Jacob, J. C., M., O. G., Gastal, E. L., and Beg, M. A. (2008). Follicle and system hormone interrelationships during spontaneous and ablation-induced ovulatory waves in mares. Anim. Reprod. Sci., 106(1-2):181-187.

Ginther, O. J., Knoph, L., and Kastelic, J. P. (1989). Temporal associations among ovarian events in cattle during oestrous cycles with two and three follicular waves. J Reprod. Fertil., 87: 223-230.

Ginther, O. J., Meira, C., Beg, M. A., and Bergfelt, D. R. (2002). Follicle and endocrine dynamics during experimental follicle deviation in mares. Biol. Reprod., 67: 862-867.

Ginther, O. J., Wiltbank, M. C., Fricke, P. M., Gibbons, J. R., and Kot, K. (1996). Selection of the dominant follicle in cattle. Biol. Rerprod., 55: 1187-1194.

Gong, J. G., Bramley, T., Gutierriz, C., Peters, A. R., and Webb, R. (1995). Effects of chronic treatment with a gonadotrpin-releasing hormone agonist on peripheral concentrations of FSH and LH, and ovarian function in heifers. J. Reprod. Fert., 105: 263-270.

Goodman, R. L., and Karsch, F. J. (1980). Pulsatile secretion of luteinizing hormone: differential suppression by ovarian steroids. Endocrinology, 100: 155-161.

Goodman, R. L., Coolen, L. M., Anderson, G. M., Hardy, S. L., Valent, M., Connors, J., Fitzgerald, M.E., and Lehman M.N. (2004). Evidence that dynorphin plays a major role in mediating progesterone negative feedback on gonadotropin-releasing hormone neurons in sheep. Endocrinology, 145:2959-2967.

Goto, Y., Matsuda-Minehata, F., Inoue, N., Matsui, T., Maeda, A., and Manabe, N. (2004). Porcine (Sus Scrofa) cellular FLICE-like inhibitory protein (cFLIP): molecular cloning and comparison with the human and murine cFLIP. J. Repro. D ev., 50: 549-555.

Grado-Ahuir, J. A., Aad, P. Y., Ranzenigo, G., Caloni, F., Cremonesi, F., and Spicer, L. J. (2009). Microarray analysis of insulin-like growth factor-I-induced changes in messenger ribonucleic acid expression in cultured porcine granulosa cells: Possible role of insulin-like growth factor-I in angiogenesis. J. Anim. Sci., 87: 1921-1933.

Greenwald, G. S. (1961). Quantitative study of follicular development in the ovary of the intact or unilaterally ovariectomized hamster. J. Reprod. Fertil., 2: 351. 
Hackett, A. J., and Hafs, H. D. (1969). Pituitary and hypothalamic endocrine changes during the bovine estrous cycle. J. Anim. Sci., 28: 531-536.

Hastie, P. M., and Haresign, W. (2008). Modulation of peripheral gonadotropin levels affects follicular expression of mRNAs encoding insulin-like growth factors and receptors in sheep. Anim. Reprod. Sci., 110-123.

Hsu, H., Xiong, J., and Goeddel, D. V. (1995). The TNF receptor-1 associated protein TRADD signals cell death and NF-кB activation. Cell, 81: 495-504.

Hsueh, A. J., Dahl, K. D., Vaughan, J., Tucker, E., Rivier, J., Bardin, C. W., et al. (1987). Heterodimers and homodimers of inhibin subunits have a different paracrine action in the modulation of luteinizing hormone-stimulated adrogen biosynthesis. Proc. Nat. Acad. Sci., 84: 5082-5086.

Hunter, J. (1787). An experiment to determine the effect of extirpating one ovarium upon the number of young produced. Phil. Trans. Roy.Soc. (London)., 77:233-239.

Hussein, T. S., Froiland, D. A., Amato, F., Thompson, J. G., and Gilchrist, R. B. (2005). Oocytes prevent cumulus cell apoptosis by maintaining a morphogenic paracrine gradient of bone morphogenetic proteins. J. Cell Sci., 118(22): 5257-5268.

Inoue, N., Maeda, A., Matsuda-Minehata, F., Fukuta, K., and Manabe, N. (2006). Expression and localization of Fas ligand and Fas during atresia in procine ovarian follicles. J . Reprod. Dev., 52(6):723-30.

Inoue, N., Manabe, N., Matsui, T., Maeda, A., Nakagawa, S., and Miyamoto, H. (2003). Roles of tumor necrosis factor-related ligand signaling pathway in granulosa cell apoptosis during atresia in pig ovaries. J. Reprod. D ev., 49: 313-321.

Ireland, J. J., and Roche, J. F. (1982). Development of antral follicles in cattle after prostaglandin-induced luteolysis: changes in serum hormones, steroids in follicular fluid, and gonadotropin receptors. Endocrinology, 111: 2077-2086.

Ireland, J. J., Coulson, P. B., and Murphree, R. L. (1979). Follicular development during the four stages of the estrous cycle of beef cattle. J. Anim. Sci., 49: 1261-1269.

Kelly, R. W., Lewer, R. P., Allison, A. J., Paterson, A., and Howarth, M. (1983). Techniques to establish flocks from fecund ewes by superovulation with and without embryo transfer. Proc. NZ Soc. Anim. Prod., 43: 205-208.

Kondo, H., Maruo, T., Peng, X., and Mochizuki, M. (1996). Immunological evidence for the expression of the Fas antigen in the infant and adult human ovaries during follicular regression and atresia. J. Clin. Endocrinol. M etab., 81: 2702-2710. 
Krysko, D. V., Diez-Fraile, A., Criel, G., Svistunov, A. A., Vandenabeele, P., and D'Herde, K. (2008). Life and death of female gametes during oogenesis and folliculogenesis. Apoptosis, 13: 1065-1087.

Kulick, L. J., Bergfelt, D. R., Kot, K., and Ginther, O. J. (2001). Follicle selection in cattle: follicle deviation and codominance within sequential waves. Biol. Reprod., 65: 839-846.

Lacker, H. M. (1981). Regulation of ovulation number in mammals: A follicle interaction law that controls maturation. Biophys. J., 35: 433-454.

Lacker, H. M., Beers, W. H., Meuli, L. E., and Akin, E. (1987). A theory of follicle selection: I. hypotheses and examples. Biol. Reprod., 37: 570-580.

Law, A. S. (1992). Evidence for the action of bovine follicular fluid factors other than inhibin in suppressing follicular development and delaying oestrus in heifers. J. Repro. F ert., 96(2): 603616.

Lee, W., and Novy, M. J. (1978). Effects of luteinizing hormone and indomethacin on blood flow and steroidogeneis in the rabbit ovary. Biol. Reprod., 18(5): 799-807.

Leung, P. C., and Armstrong, D. T. (1980). Interactions of steroids and gonadotropins in the control of steroidogenesis in the ovarian follicle. Ann. Rev. Physiol., 42: 71-82.

Lipschutz, A. (1928). New developments in ovarian dynamics and the law of follicular constancy. J. Exp. Biol., 4: 283- 291.

Mallampati, R. S., and Casida, L. E. (1970). Ovarian compensatory hypertrophy following unilateral ovariectomy during the breeding season in the ewe. Biol. Reprod., 3: 43-46.

Mandl, A. M., and Zuckerman, S. (1951). Numbers of normal and atretic oocytes in unilaterally spayed rats. J. Endocrin., 7: 112.

Martin, G. G., and Talbot, P. (1981a). The role of follicular smooth muscle cells in hamster ovulation. J. Exp. Zool., 216: 469-482.

Martin, G., and Talbot, P. (1981b). Drugs that block smooth muscle contraction inhibit in vivo ovulation in hamsters. J. Exp. Zool., 216: 483-491.

Matova, N., and Cooley, L. (2001). Comparative aspects of animal oogenesis. D ev. Biol., 231: 291-320.

Matsuda-Minehata, F., Goto, Y., Inoue, N., and Manabe, N. (2005). Changes in the expression of anti-apoptotic protein, cFLIP, in granulosa cell during follicular atresia in porcine ovaries. M ol. Reprod. Dev., 72: 145-151. 
Matsuda-Minehata, F., Inoue, N., Goto, Y., and Manabe, N. (2006). The regulation of ovarian granulosa cell death by pro- and anti-apoptotic molecules. J. Reprod. D evelop., 52 (6): 695-705.

Matsuda-Minehata, Inoue, N., Goto, Y., and Manabe, N. (2006). The regulation of ovarian granulosa cell death by pro- and anti-apoptotic molecules. J. Reprod. Dev., 52(6): 695-705.

Matton, P., Adelakoun, V., Couture, Y., and Dufour, J. J. (1981). Growth and replacement of the bovine ovarian follicles during the estrous cycle. J . Anim. Sci., 52: 813-820.

McNatty, K. P., Smith, P., Hudson, N. L., Heath, D. A., Tisdall, D. J., and Braw-Tal, R. (1995). Development of the sheep ovary during fetal and early neonatal life and the effect of fecundity genes. J. Rerprod. F ertil. Suppl., 49: 123-135.

Medema, J. P., Scaffidi, C., Kischkel, F. C., Shevchenko, A., Mann, M., Krammer, P. H., and Peter, M.E. (1997). FLICE is activated by association with the CD95 death-inducing complex (DISC). Embo J ., 16:2794-2804.

Merz, E. A., Henning, G. F., and Casida, L. E. (1977). An attempt to induce multiple ovulations in beef cows by unilateral ovariectomy and hCG administration. J. Anim. Sci., 46(3): 492-495.

Mohan, M., and Rajamahendran, R. (1997). Effects of unilateral ovariectomy on follicular development and ovulation in cattle. Theriogenology, 49: 1059-1070.

Monniaux, D., and Pisselet, C. (1994). Control of proliferation and differentiation of ovine granulosa cells by insulin-like growth factor-I and follicle-stimulation hormone in vitro. Biol. Reprod., 142: 497-510.

Motta, P., and Van Blerkom, J. (1975). A scanning electron microscope study of the luteofollicular complex. II. Events leading to ovulation. Amer. J . Anat., 143: 241-264.

Mulsant, P., Lecerf, F., Fabre, S., Schibler, L., and Monget, P. (2001). Mutation in bone morphogenetic protein receptor-IB is associated with increased ovulation rate in Booroola Merino ewes. Proc. Natl. Acad. Sci., 98: 5104-5109.

Nishi, Y., Yanase, T., Mu, Y., Oba, K., Ichino, I., Saito, M., et al. (2001). Establishment and characterization of a steroidogenic human granulosa-like tumor cell line, KGN, that expresses functional follicle-stimulating hormone receptor. Endocrinology, 142: 437-445.

Okamura, H., Virutamasen, P., and Wright, K. H. (1972). Ovarian smooth muscle in the human being, rabbits, and cat. Amer. J . O bstet. Gynecol., 112: 183-191.

O'Shea, J. D. (1970). An ultrastructural study of smooth muscle-like cells in the theca externa of ovarian follicles in the rat. Anat. Rec., 167: 127-140. 
Pendergrass, P. B., and Reber, M. (1980). Scanning electron microsopy of the Graafian follicle during ovulation in the golden hamster. J. Reprod. Fert., 59(10): 21-24.

Pierson, R. A., and Ginther, O. J. (1987). Follicular populations during the estrous cycle in heifers I. Influence of day. Anim. Reprod. Sci., 14: 165-176.

Pierson, R. A., and Ginther, O. J. (1984). Ultrasonography of the bovine ovary. Theriogenology, 21: 495-504.

Pieterse, M. C., Vos, P., Kruip, T. A., and Taverne, M. A. (1988). Aspiration of bovine oocytes during transvaginal ultrasound scanning of the ovaries. Theriogenology, 30:751-762.

Pinchas, C. (2008). Overview of the IGF-I System. H ormone Research, 65 (suppl 1): 3-8.

Piper L.H. and Bindon B.M. (1982). The Booroola Merino and the performance of medium non-peppin crosses at Armidale. In The Booroola M erin: 9-20 CSIRO, Melbourne

Piper, L. R., Bindon, B. M., and Davis, G. H. (1985). The single gene inheritance of the high litter size of the Booroola Merino. In Genetics of Reproduction in Sheep (pp. 115-125). London: Butterworths.

Prange-Kiel, J., Kreutzkamm, C., Wehrenberg, U., and Rune, G. M. (2001). Role of tumor necrosis factor in preovulatory follicles of swine. Biol. Reprod., 65: 928-935.

Rajakoski, E. (1960). The ovarian follicular system in sexually mature heifers with special reference to seasonal, cyclical, and left-right variations. Acta. Endocrinol., 34: 7-68.

Rhodes, F. M., De'ath, G., and Entwistle, K. W. (1995). Animal and temporal effects on ovarian follicular dynamics in Brahman heifers. Anim. Reprod. Sci., 38: 265-277.

Richards, J. S. (1980). Maturation of ovarian follicles: actions and interactions of pituitary and ovarian hormones on follicular cell differentiation. Physiol. Rev., 60: 51-89.

Rivera, G. M., and Fortune, J. E. (2001). Development of codominant follicles in cattle is associated with a follicle-stimulating hormone-dependent insulin-like growth factor binding protein-4 protease. Biol. Reprod., 65: 112-118.

Roche, J. F., and Ireland, J. J. (1981). The differential effects of progesterone on concentrations of lutenizing hormone and follicle-stimulating hormone in heifers. Endocrinology, 108: 568572.

Rondel, P. (1974). Role of steroid synthesis in the process of ovulation. Biol. Reprod., 10(2): 199-215

Rosenfeld, R. G., Hwa, V., Wilson, E., Plymate, S. R., and Oh, Y. (2000). The insulin-like growth factor-binding protein superfamily. Growth Horm. IG F Res., 10 (Suppl A): S16-17. 
Saiduddin, S., Rowe, R. F., and Casida, L. E. (1970). Ovarian follicular changes following unilateral ovariectomy in the cow. Biol. Reprod., 2: 408-412.

Sakamaki, K., Yoshida, H., Nishimura, Y., Nishikawa, S., Nanabe, N., and Yonehara, S. (1997). Involvement of Fas antigen in ovarian follicular atresia and luteolysis. M ol. Reprod. D ev., 47: 11-18.

San Roman, G. A., and Magoffin, D. A. (1993). Insulin-like growth factor-binding proteins in healthy and atretic follicles during natural menstrual cycles. J . Clin. Endocrinol. M etab., 76(3): 625-632.

Savio, J. D., Keenan, L., Boland, M. P., and Roche, J. F. (1988). Pattern of growth of dominant follicles during the oestrous cycle in heifers. J. Reprod. Fertil., 83: 663-671.

Scaffidi, C., Fulda, S., Srinivasan, A., Friesen, C., Li, F., Tomaselli, K. J., Debatin K.M., Krammer, P.H., and Peter, M.E. (1998). Two CD95 (APO-1/Fas) signalling pathways. E mbo. J., 17: 1675-1687.

Schams, D., Berisha, B., Kosmann, M., and Amselgruber, W. M. (2002). Expression and localization of IGF family members in bovine antral follicles during final growth and in luteal tissue during different stages of estrous cycle and pregnancy. Dom. Anim. Endocrinol., 22: 5172.

Schneyer, A. L., Fujiwara, T., Fox, J., Welt, C., Adams, J., Messerlian, G., and Taylor A.E. (2000). Dynamic changes in the intrafollicular inhibin/activin/follistatin axis during human follicular development: relationship to circulating hormone concentrations. J . Clin. Endocrinol. M etab., 85(9): 3319-3330.

Silva, J. M., and Price, C. A. (2002). Insulin and IGF-I are necessary for FSH-induced cytochrome $\mathrm{P} 450$ aromatase but not cytochrome P450 side-chain cleavage gene expression in oestrogenic bovine granulosa cells in vitro. J. Endocrinol., 174: 599-507.

Sirois, J., and Fortune, J. E. (1988). Ovarian follicular dynamics during the estrous cycle in heifers monitored by real-time ultrasonography. Biol. Reprod., 39: 308-317.

Song, R. X., Barnes, C. J., Zhang, Z., Bao, Y., Kumar, R., and Santen, R. J. (2004). The role of Shc and insulin-like growth factor 1 receptor in mediating the translocation of estrogen receptor $\alpha$ to the plasma membrane. Proc. Nat. Acad. Sci., 101(7): 2076-2081.

Souza, C. J., Campbell, B. K., McNeilly, A. S., and Baird, D. T. (2001). Bone morphogenetic proteins and folliculogenesis: lessons from the Booroola muation. Reprod. Suppl., 61: 361-370.

Souza, C. J., Campbell, B. K., McNeilly, A. S., and Baird, D. T. (2002). Effect of bone morphogenetic protin 2 (BMP 2) on oestradiol and inhibin A production by sheep granulosa 
cells, and localization of BMP receptors in the ovary by immunohistochemistry. Reproduction, 123: 363-369.

Stumpf, T. T., Roberson, M. S., Wolfe, M. W., Hamernik, K. L., Kittok, R. L., and Kinder, J. E. (1993). Progesterone, $17 \beta$-estradiol, and opioid neuropeptides modulate pattern of luteinizing horomone in circulation of the cow. Biol. Reprod., 49: 1096-1101.

Sudo, N., Shimizu, T., Kawashima, C., Kaneko, E., Tetsuka, M., and Miyamoto, A. (2007). Insulin-like growth factor-I (IGF-I) system during follicle development in the bovine ovary: relationships among IGF-I, type 1 receptor (IGFR-1) and pregnancy-associated plasma proteinA (PAPP-A). Mol. Cell. Endocrinol., 197-203.

Tamura, K., Matsushita, M., Endo, A., Kutsukake, M., and Kogo, H. (2007). Effect of insulinlike growth factor protein 7 on steroidogenesis in granulosa cells derived from equine chorionic gronadotropin-primed immature rat ovaries. Biol. Reprod., 77: 485-491.

Tian, X. C., Berndtson, A. K., and Fortune, J. E. (1995). Differentiation of bovine preovulatory follicles during the follicular phase is associated with increases in messenger ribonucleic acid for cytochrome P450 side-chain cleavage, 3 $\beta$-hydroxysteroid dehydrogenase, and P450 17 $\alpha$ hydroxylase, but not P450 aromatase. Endocrinology, 136(11): 5102-5110.

Townson, D.H., Tsang, P.C., Butler, W.C., Frajblat, M., Griel Jr,, L.C., Johnson, C.J., Milvae, R.A., Niksic M., and Pate J.L.. (2002). Relationship of fertility to ovarian follicular waves before breeding in dairy cows. J. Anim. Sci., 80: 1053-1058.

Van Dessel, H. J., Chandrasekher, Y. A., Yap, O. W., Lee, P. D., Hintz, R. L., and Faessen, G. H. (1996). Serum and follicular fluid levels of IGF-I, IGF-II, IGF binding protein-1 (IGFBP-1) and IGFBP-3 during the normal menstrual cycle. J. Clin. Endocrinol. M etab., 81: 1224-31.

Walles, B., Edvinsson, L., Falck, B., Owman, C., Sjoberg, N. O., and Svensson, K. (1975). Evidence for a neuromuscular mechanism involved in the contractility of the ovarian follicular wall: fluorescence and electron microscopy and effects of tyramine on follicle strips. Biol. Reprod., 12: 239-248.

Wandji, S. A., Srsen, V., Voss, A. K., Eppig, J. J., and Fortune, J. E. (1996). Initiation in vitro of growth of bovine primordial follicles. Biol. Reprod., 55: 942-948.

Welt, C. K., and Schneyer, A. L. (2001). Differential regulation of inhibin B and inhibin A by follicle-stimulating hormone and local growth factors in human granulosa cells from small antral follicles. J. Clin. Endocrinol. M etab., 86(1): 330-336.

Wood, S. C. (1992). The ability of steroid-free bovine follicular fluid to suppress FSH secretion and delay ovulation persists in heifers immunized against inhibin. J . Endo., 136: 137-148. 
Xiao, C. W., Asselin, E., and Tsang, B. K. (2002). Nuclear factor $\kappa$ B-mediated induction of Flice-like inhibitory protein prevents tumor necrosis factor $\alpha$-induced apoptosis in rat granulosa cells. Biol. Reprod., 67: 436-441.

Xu, Z., Garverick, H. A., Smith, G. W., Smith, M. F., Hamilton, S. A., and Youngquist, R. S. (1995). Expression of follicle-stimulating hormone and luteinizing hormone receptor messenger ribonucleic acids in bovine follicles during the first follicular wave. Biol. Reprod., 53: 951-957.

Yang, M. Y., and Fortune, J. E. (2006). Testosterone stimulates the primary to secondary follicle transition in bovine follicles in vitro. Biol. Reprod., 75(6): 924-932.

Yang, M. Y., and Fortune, J. E. (2008). The capacity of primordial follicles in fetal bovine ovaries to inititate growth develops during mid-gestation and is associated with meiotic arrest of oocytes. Biol. Reprod., 78(6): 1153-1161.

Yang, M. Y., and Fortune, J. E. (2007). Vascular endothelial growth factor stimulates the primary to secondary follicle transition in bovine follicles in vitro. M ol. Reprod. D ev., 74(9): 1095-1104.

Yuan, J. S., Reed, A., Chen, F., and Stewart Jr., C. N. (2006). Statistical analysis of real-time PCR data. BM C Bioinformatics, 7: 85- 97.

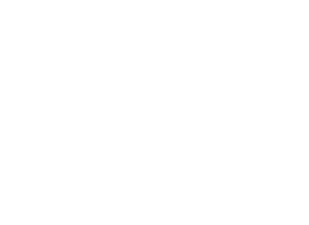

